\title{
LC-ESI-QTOF-MS/MS Profiling and Antioxidant Activity of Phenolics from Custard Apple Fruit and By-Products
}

\author{
Junxi Du ${ }^{1}$, Biming Zhong ${ }^{1}$, Vigasini Subbiah ${ }^{1}$, Colin J. Barrow ${ }^{2} \mathbb{D}$, Frank R. Dunshea ${ }^{1,3} \mathbb{D}$ \\ and Hafiz A. R. Suleria $1,2, *$ (i) \\ 1 Faculty of Veterinary and Agricultural Sciences, School of Agriculture and Food, \\ The University of Melbourne, Parkville, VIC 3010, Australia; junxid@student.unimelb.edu.au (J.D.); \\ bimingz@student.unimelb.edu.au (B.Z.); vsubbiah@student.unimelb.edu.au (V.S.); \\ fdunshea@unimelb.edu.au (F.R.D.) \\ 2 Centre for Chemistry and Biotechnology, School of Life and Environmental Sciences, Deakin University, \\ Waurn Ponds, VIC 3217, Australia; colin.barrow@deakin.edu.au \\ 3 Faculty of Biological Sciences, The University of Leeds, Leeds LS2 9JT, UK \\ * Correspondence: hafiz.suleria@unimelb.edu.au; Tel.: +61-470-439-670
}

\section{check for} updates

Citation: Du, J.; Zhong, B.; Subbiah, V.; Barrow, C.J.; Dunshea, F.R.; Suleria, H.A.R. LC-ESI-QTOF-MS/MS

Profiling and Antioxidant Activity of Phenolics from Custard Apple Fruit and By-Products. Separations 2021, 8 , 62. https://doi.org/10.3390/ separations 8050062

Academic Editors:

Maykel Hernández-Mesa and David Moreno-González

Received: 2 April 2021

Accepted: 6 May 2021

Published: 9 May 2021

Publisher's Note: MDPI stays neutral with regard to jurisdictional claims in published maps and institutional affiliations.

Copyright: (c) 2021 by the authors. Licensee MDPI, Basel, Switzerland. This article is an open access article distributed under the terms and conditions of the Creative Commons Attribution (CC BY) license (https:// creativecommons.org/licenses/by/ $4.0 /)$.

\begin{abstract}
Custard apple is an edible fruit grown in tropical and subtropical regions. Due to its abundant nutrient content and perceived health benefits, it is a popular food for consumption and is utilized as a medicinal aid. Although some published research had provided the phenolic compound of custard apple, the comprehensive phenolic profiling of Australian grown custard apple is limited. Hence, this research aimed to evaluate the phenolic content and antioxidant potential by various phenolic content and antioxidant assays, followed by characterization and quantification of the phenolic profile using LC-ESI-QTOF-MS/MS and HPLC-PDA. African Pride peel had the highest value in TPC (61.69 $\pm 1.48 \mathrm{mg} \mathrm{GAE} / \mathrm{g})$, TFC $(0.42 \pm 0.01 \mathrm{mg} \mathrm{QE} / \mathrm{g})$ and TTC (43.25 $\pm 6.70 \mathrm{mg}$ CE/g), followed by Pink's Mammoth peel (19.37 $\pm 1.48 \mathrm{mg}$ GAE/g for TPC, $0.27 \pm 0.03 \mathrm{mg} \mathrm{QE} / \mathrm{g}$ for TFC and $10.25 \pm 1.13 \mathrm{mg} \mathrm{CE} / \mathrm{g}$ for TTC). African Pride peel also exhibited the highest antioxidant potential for TAC (43.41 $\pm 1.66 \mathrm{mg} \mathrm{AAE} / \mathrm{g}), \mathrm{FRAP}(3.60 \pm 0.14 \mathrm{mg}$ $\mathrm{AAE} / \mathrm{g})$ and ABTS $(127.67 \pm 4.60 \mathrm{mg}$ AAE/g), whereas Pink's Mammoth peel had the highest DPPH (16.09 $\pm 0.34 \mathrm{mg}$ AAE/g), RPA (5.32 $\pm 0.14 \mathrm{mg} \mathrm{AAE} / \mathrm{g}), \bullet^{\bullet} \mathrm{OH}-\mathrm{RSA}(1.23 \pm 0.25 \mathrm{mg}$ AAE/g) and FICA (3.17 $\pm 0.18 \mathrm{mg}$ EDTA/g). LC-ESI-QTOF-MS/MS experiment successfully characterized 85 phenolic compounds in total, encompassing phenolic acids (20), flavonoids (42), stilbenes (4), lignans (6) and other polyphenols (13) in all three parts (pulp, peel and seeds) of custard apple. The phenolic compounds in different portions of custard apples were quantified by HPLC-PDA, and it was shown that African Pride peel had higher concentrations of the most abundant phenolics. This is the first study to provide the comprehensive phenolic profile of Australian grown custard apples, and the results highlight that each part of custard apple can be a rich source of phenolics for the utilization of custard apple fruit and waste in the food, animal feeding and nutraceutical industries.
\end{abstract}

Keywords: custard apple; phenolic compounds; antioxidant potential; LC-ESI-QTOF-MS/MS; HPLC-PDA

\section{Introduction}

Custard apples are popular commercial fruits widely grown in tropical and subtropical areas [1]. These fruits offer pleasant flavor and creamy taste and have high nutritional values. In Australia, the annual production of fresh custard apple is 3000 tons, and the soft edible pulp portion of the fruits is used to make different food products such as jams, candies and drinks [2,3]. Soursop (Annona muricata) custard apple, also called 'graviola' and 'guanabana', is a traditional custard apple fruit mainly grown for its edible and medicinal purposes. Soursop is used in commercial food products, including juice, candies and sherbets [4]. African Pride (Annona atemoya cv.) and Pink's Mammoth (Annona atemoya cv.) 
are two other popular custard apple cultivars. African Pride variety is rich in phytochemicals (catechin and epicatechin gallate) and phytonutrients, including carbohydrates and crude proteins, whereas Pink's Mammoth has a high mineral content, including calcium and zinc [5].

Phytochemicals present in custard apples recently gained substantial interest, particularly for the investigation of phenolic compounds [6]. Polyphenols are secondary metabolites abundantly present in different plants, including fruits, vegetables and medicinal plants. They can be classified into five major classes, namely phenolic acids, flavonoids, lignans, stilbenes and phenol alcohols based on the structure [7]. Polyphenols can act as antioxidants that scavenge free radicals directly or indirectly via various mechanisms. The free radical scavenging capacity of polyphenols is related to their structure, by donating either hydrogen atoms or electrons to free radicals and stabilizing the reactive species [8]. Phenolic content can be evaluated by various assays, including total phenolic content (TPC), total flavonoid content (TFC) and total tannin content (TTC), while the antioxidant capacity of plants can be effectively measured and estimated by a series of assays, including $2,2^{\prime}-$ diphenyl-1-picrylhydrazyl (DPPH), 2,2'-azino-bis-3-ethylbenzothiazoline-6-sulfonic acid (ABTS), ferric reducing antioxidant power (FRAP), reducing power activity assay (RPA), hydroxyl radical scavenging activity $\left({ }^{\bullet} \mathrm{OH}-\mathrm{RSA}\right)$, ferrous ion chelating activity (FICA) and total antioxidant capacity (TAC) [8].

Apart from measuring the phenolic contents and antioxidant potential, the separation and characterization of individual phenolic compounds with strong antioxidant potential in custard apples are of great interest. Previously, several phenolic compounds such as catechin and epicatechin have been identified in different custard apples using highperformance liquid chromatography equipped with a photodiode array (HPLC-PDA) and LC-MS/MS techniques [1,9]. Liquid chromatography coupled with quadrupole time-offlight mass spectrometry (LC-MS-QTOF-MS/MS) is a high-resolution and highly sensitive technique widely used for the screening and characterization of phenolic compounds in different plant materials, whereas HPLC-PDA allows the quantification of phenolic compounds $[10,11]$. Although researchers have reported some bioactive compounds from custard apple fruits, only a few studies have focused on the whole phenolic profiles of Australian grown custard apples. In addition, there is a lack of studies on waste material such as peel and seed of custard apples which have the potential to be utilized for extraction of bioactive compounds.

In the present research, the phenolic profiles of three different Australian grown custard apples (soursop, African Pride and Pink's Mammoth) were characterized using LC-ESI-QTOF-MS/MS and quantified through HPLC-PDA. Further analyses, which included the TPC, TFC and TTC measurements and DPPH, ABTS, FRAP, RPA, ${ }^{\circ} \mathrm{OH}-\mathrm{RSA}$, FICA and TAC antioxidant assays, were performed. The outcome of this study enables us to understand the phenolic composition of different Australian grown custard apples for their commercial utilization in the preparation of functional, nutraceutical and pharmaceutical products.

\section{Materials and Methods}

\subsection{Chemicals and Reagents}

Most of the chemicals used for the extraction and characterization were analytical grade and purchased from Sigma-Aldrich (Castle Hill, NSW, Australia). Folin-Ciocalteu phenol reagent, vanillin $(\geq 97 \%)$, gallic acid $(\geq 98 \%)$, aluminum chloride hexahydrate $(\geq 98 \%)$, ascorbic acid $(\geq 99 \%)$, quercetin $(\geq 95 \%)$, catechin ( $\geq 96 \%), 2,2^{\prime}$-diphenyl-1-picrylhydrazyl (DPPH), 2,4,6-tripyridyl-s-triazine (TPTZ) ( $\geq 98 \%$ ), $\mathrm{HCl}$ ( $\geq 99 \%$ ), 2,2'-azino-bis(3-ethylbenzothiazoline-6sulfonic acid) (ABTS) $(\geq 98 \%)$ and potassium persulfate $(\geq 99 \%)$ were purchased from SigmaAldrich (St. Louis, MO, USA) for the estimation of phenolic content and a series of antioxidant measurement trials. Sodium carbonate $(\geq 99.5 \%)$, sulfuric acid $(\geq 95 \%)$, ethanol $(\geq 99.5 \%)$, acetic acid $(\geq 99 \%)$, ferric chloride $\left(\mathrm{Fe}(\mathrm{III}) \mathrm{Cl}_{3} \cdot 6 \mathrm{H}_{2} \mathrm{O}\right)(\geq 97 \%)$ and sodium acetate $(\geq 99.5 \%)$, were purchased from Thermo Fisher (Scoresby, Melbourne, VIC, Australia). Methanol 
(HPLC Grade, 99.8\%), acetic acid ( $\geq 99 \%$ ) and acetonitrile ( $\geq 99.9 \%$ ) were purchased from Sigma-Aldrich (St. Louis, MO, USA) for HPLC. The HPLC standards, including quercetin $(\geq 95 \%)$, protocatechuic acid $(\geq 97 \%), p$-coumaric acid $(\geq 98.0 \%)$, catechin $(\geq 98 \%)$, chlorogenic acid $(\geq 95 \%)$, epicatechin $(\geq 98 \%)$, quercetin-3-rhamnoside $(\geq 97 \%)$, $p$-hydroxybenzoic acid ( $\geq 97 \%)$, syringic acid $(\geq 95 \%)$ and quercetin-3-glucoside $(\geq 95 \%)$, were purchased from Sigma-Aldrich (St. Louis, MO, USA).

\subsection{Sample Preparation}

Three physiologically mature Australian grown custard apples (soursop, African Pride and Pink's Mammoth) were purchased from a retail market in Melbourne, Australia. The fruits were cleaned and separated into peel, pulp and seed portions. Samples were trimmed into slices, freeze-dried at $-20^{\circ} \mathrm{C}$ for $48 \mathrm{~h}$ and lyophilized at $-45^{\circ} \mathrm{C} / 50 \mathrm{MPa}$ by Dynavac engineering FD3 Freeze Drier ( Belmont, WA, Australia) and Edwards RV12 oilsealed rotary vane pump (Bolton, UK) [12]. The freeze-dried peels, seeds and pulps were ground into powders and stored at $-20^{\circ} \mathrm{C}$.

\subsection{Extraction of Phenolic Compounds}

Five grams of each sample was extracted by $15 \mathrm{~mL}$ of $80 \%$ ethanol [13]. All samples were homogenized with an Ultra-Turrax T25 Homogenizer for $30 \mathrm{~s}$ at 10,000 rpm (IKA, Staufen, Germany), followed by the incubation at $120 \mathrm{rpm}$ and $4{ }^{\circ} \mathrm{C}$ for $18 \mathrm{~h}$ in a shaker incubator (ZWYR-240, Labwit, Ashwood, VIC, Australia). After incubation, samples were centrifuged by refrigerated Centrifuge (Hettich Rotina 380R, Tuttlingen, Germany) at $5000 \mathrm{rpm}$ for $15 \mathrm{~min}$. The supernatant was immediately collected and stored at $-20^{\circ} \mathrm{C}$ for further analysis.

\subsection{Polyphenol Estimation and Antioxidant Assays}

The estimation of polyphenols was performed by three assays (TPC, TFC and TTC), while the antioxidant capacity was measured by seven diverse assays (DPPH, FRAP, ABTS, RPA, $\bullet$ OH-RSA, FICA and TAC). All these methods except TAC were reported by Gu et al. [14], Zhu et al. [15] and Suleria et al. [16]. The data were acquired by the Multiskan Go microplate photometer (Thermo Fisher Scientific, Waltham, MA, USA).

\subsubsection{Determination of Total Phenolic Content (TPC)}

The total phenolic content of the extracts was determined by the Folin-Ciocalteu method with some modifications [17]. A $25 \mu \mathrm{L}$ aliquot of extract was mixed with FolinCiocalteu reagent solution and $200 \mu \mathrm{L}$ water in a 96-well plate (Corning Inc., Midland, $\mathrm{NC}$, USA). A $5 \mathrm{~min}$ incubation at room temperature was required before $25 \mu \mathrm{L} 10 \%$ (w:w) sodium carbonate was added. A further incubation $(60 \mathrm{~min})$ at $25^{\circ} \mathrm{C}$ in a dark room was performed, followed by the measurement of absorbance at $765 \mathrm{~nm}$ by a spectrophotometer plate reader. The quantification of total phenolic content was based on a standard curve generated from gallic acid with concentrations from 0 to $200 \mu \mathrm{g} / \mathrm{mL}$, and the results were expressed as $\mathrm{mg}$ of gallic acid equivalents per gram (mg GAE/g).

\subsubsection{Determination of Total Flavonoid Content (TFC)}

The total flavonoid contents were estimated by the modified aluminum chloride method [18]. An $80 \mu \mathrm{L}$ aliquot of extract was transferred to a 96-well plate and subsequently mixed with $80 \mu \mathrm{L}$ of $2 \%$ ethanolic aluminum chloride and $120 \mu \mathrm{L}$ of $50 \mathrm{~g} / \mathrm{L}$ sodium acetate solution before being transferred to a dark room and incubated at $25^{\circ} \mathrm{C}$ for $2.5 \mathrm{~h}$. The quantification of total phenolic content was based on a standard curve generated from quercetin with concentrations from 0 to $50 \mu \mathrm{g} / \mathrm{mL}$, and the results were expressed as $\mathrm{mg}$ of quercetin equivalents per gram (mg QE/g). 


\subsubsection{Determination of Total Tannin Content (TTC)}

The total tannin contents were determined by a vanillin-sulfuric acid method with some modification [19]. Twenty-five microliters of $32 \%$ sulfuric acid was added to $25 \mu \mathrm{L}$ of sample and $150 \mu \mathrm{L}$ of $4 \%$ vanillin solution in a 96-well plate which was then incubated at room temperature for $15 \mathrm{~min}$ in a dark room. Subsequently, the measurement of absorbance was carried out at $500 \mathrm{~nm}$ by using the plate reader. The quantification of total tannin content was based on a standard curve generated from catechin with concentrations from 0 to $100 \mu \mathrm{g} / \mathrm{mL}$, and the results were expressed as $\mathrm{mg}$ of catechin equivalents (CE) per gram (mg CE/g).

\subsubsection{2,2'-Diphenyl-1-Picrylhydrazyl (DPPH) Assay}

The DPPH assay was adopted to examine the free radical scavenging ability, and the procedure had some modifications made to the published method [20]. A $40 \mu \mathrm{L}$ aliquot of extract was mixed with $260 \mu \mathrm{L}$ of DPPH ethanolic solution $(0.1 \mathrm{mM})$ in a 96-well plate. Further, the plate was incubated for $30 \mathrm{~min}$ at $25^{\circ} \mathrm{C}$. The absorbance was measured at $517 \mathrm{~nm}$, and the result was quantified by a calibration curve generated by ascorbic acid with gradient concentrations $(0-50 \mu \mathrm{g})$ and expressed as $\mathrm{mg}$ of ascorbic acid equivalents per g (mg AAE/g).

\subsubsection{Ferric Reducing Antioxidant Power (FRAP) Assay}

The FRAP assay measured the capacity of extracts to reduce the ferric ions to ferrous ions, and the method adopted in this study was modified according to a previous method [20]. The FRAP reagent was prepared by mixing sodium acetate solution $(300 \mathrm{mM})$, 2,4,6-tripyridyl-s-triazine (TPTZ) solution $(10 \mathrm{mM})$ and Fe(III) solution $(20 \mathrm{mM})$ in the ratio of 10:1:1. A $20 \mu \mathrm{L}$ aliquot of extract was added to a 96-well plate and was then mixed with $280 \mu \mathrm{L}$ of prepared FRAP reagents followed by incubation at $37^{\circ} \mathrm{C}$ for $10 \mathrm{~min}$. The measurement of absorbance was performed at $593 \mathrm{~nm}$ in a plate reader. Ascorbic acid with a series of dilutions (ranging from 0 to $50 \mu \mathrm{g} / \mathrm{mL}$ ) was used to plot a standard curve, and the results were expressed as mg of ascorbic acid equivalents per $\mathrm{g}(\mathrm{mg} \mathrm{AAE} / \mathrm{g})$.

\subsubsection{2,2'-Azino-Bis-3-Ethylbenzothiazoline-6-Sulfonic Acid (ABTS) Assay}

The estimation of ABTS scavenging activity was performed by modifying $\mathrm{ABTS}^{+}$ radical cation decolorization assay [20]. The $\mathrm{ABTS}^{+}$radical solution was prepared by mixing $7 \mathrm{mmol} / \mathrm{L}$ of ABTS solution with $140 \mathrm{mM}$ potassium persulfate solution, followed by storage in a dark room for $16 \mathrm{~h}$. Further dilution of the solution with ethanol was required to give absorbance at $734 \mathrm{~nm}$. A $10 \mu \mathrm{L}$ aliquot of extract and $290 \mu \mathrm{L}$ diluted solution were mixed in a 96-well plate and then incubated at room temperature for $6 \mathrm{~min}$ in the dark. Further, the measurement of absorbance was performed at $734 \mathrm{~nm}$ in a plate reader. The results were expressed as $\mathrm{mg}$ of ascorbic acid equivalent per $\mathrm{g}(\mathrm{mg}$ $\mathrm{AAE} / \mathrm{g}$ ), and the standard curve was generated with a series of dilutions of ascorbic acid concentrations ranging from 0 to $2000 \mu \mathrm{g} / \mathrm{mL}$.

\subsubsection{Reducing Power Assay (RPA)}

The reducing power activity was determined by modifying the method of Ferreira et al. [21]. Sequential addition of $10 \mu \mathrm{L}$ of extract, $25 \mu \mathrm{L}$ of $0.2 \mathrm{M}$ sodium phosphate buffer ( $\mathrm{pH}$ 6.6) and $25 \mu \mathrm{L}$ of $\left.\mathrm{K}_{3}\left(\mathrm{Fe}(\mathrm{CN})_{6}\right]\right)$ was followed by incubation at $25^{\circ} \mathrm{C}$ for $20 \mathrm{~min}$. Then, $25 \mu \mathrm{L}$ of $10 \%$ TCA solution was added to stop the reaction, followed by the addition of $85 \mu \mathrm{L}$ of water and $8.5 \mu \mathrm{L}$ of $\mathrm{FeCl}_{3}$. The solution was further incubated for $15 \mathrm{~min}$ at $25^{\circ} \mathrm{C}$. Then, the absorbance was measured at $750 \mathrm{~nm}$. Ascorbic acid from 0 to $500 \mu \mathrm{g} / \mathrm{mL}$ was used to obtain a standard curve, and data were presented as $\mathrm{mg} \mathrm{AAE} / \mathrm{g} \mathrm{fw}$.

\subsubsection{Hydroxyl Radical Scavenging Activity $\left(\bullet^{\bullet} \mathrm{OH}-\mathrm{RSA}\right)$}

The Fenton-type reaction method of Smirnoff and Cumbes [22] was used to determine - OH-RSA with some modifications. Fifty microliters of extract was mixed with $50 \mu \mathrm{L}$ of 
$6 \mathrm{mM} \mathrm{FeSO} 4.7 \mathrm{H}_{2} \mathrm{O}$ and $50 \mu \mathrm{L}$ of $6 \mathrm{mM} \mathrm{H}_{2} \mathrm{O}_{2}(30 \%)$, followed by incubation at $25^{\circ} \mathrm{C}$ for $10 \mathrm{~min}$. After incubation, $50 \mu \mathrm{L}$ of $6 \mathrm{mM}$ 3-hydroxybenzoic acid was added, and absorbance was measured at a wavelength of $510 \mathrm{~nm}$. Ascorbic acid from 0 to $300 \mu \mathrm{g} / \mathrm{mL}$ was used to obtain a standard curve, and data were presented as mg AAE/g fw.

\subsubsection{Ferrous Ion Chelating Activity (FICA)}

The $\mathrm{Fe}^{2+}$ chelating activity of the sample was measured according to the method of Dinis et al. [23] with modifications. Fifteen microliters of extract was mixed with $85 \mu \mathrm{L}$ of water, $50 \mu \mathrm{L}$ of $2 \mathrm{mM}$ ferrous chloride (with additional 1:15 dilution in water) and $50 \mu \mathrm{L}$ of $5 \mathrm{mM}$ ferrozine (with additional 1:6 dilution in water), followed by incubation at $25{ }^{\circ} \mathrm{C}$ for $10 \mathrm{~min}$. Then, the absorbance was measured at a wavelength of $562 \mathrm{~nm}$. Ethylenediaminetetraacetic acid (EDTA) in concentrations from 0 to $30 \mu \mathrm{g} / \mathrm{mL}$ was used to obtain a standard curve, and data were presented as mg EDTA/g fw.

\subsubsection{Determination of Total Antioxidant Capacity (TAC)}

The total antioxidant capacity was measured by the modified TAC assay [24]. The TAC reagent was prepared by mixing $0.6 \mathrm{M} \mathrm{H}_{2} \mathrm{SO}_{4}, 28 \mathrm{mM} \mathrm{Na}_{3} \mathrm{PO}_{4}$ and $4 \mathrm{mM}$ ammonium molybdate. The extract was mixed with the prepared dye in a 96-well plate, followed by incubation at $95^{\circ} \mathrm{C}$ for $90 \mathrm{~min}$. The plate was then cooled at room temperature for $10 \mathrm{~min}$, and the absorbance was measured at $765 \mathrm{~nm}$ in a microplate photometer. The results were expressed as mg ascorbic acid equivalents per gram (mg AAE/g), and the standard curve was generated by series dilution of ascorbic acid solution ranging from 0 to $300 \mu \mathrm{g} / \mathrm{mL}$.

\subsection{Characterization of Phenolic Compounds through LC-ESI-QTOF-MS/MS}

The characterization of phenolic compounds was carried out by LC-ESI-QTOF-MS/MS by adapting the method of Zhong et al. [25]. The process was performed on an Agilent 1200 series HPLC (Agilent Technologies, CA, USA) equipped with an Agilent 6520 AccurateMass Q-TOF LC-MS/MS (Agilent Technologies, CA, USA). A Synergi Hydro-RP $80{ }^{\circ} \mathrm{A}$ LC reverse-phase column with the diameter of $250 \times 4.6 \mathrm{~mm}$ inside and particle diameter of $4 \mu \mathrm{m}$ (Phenomenex, Torrance, CA, USA) was used for the separation of compounds. Mobile phase A was prepared with acetic acid/water $(0.5: 99.5, v / v)$, while mobile phase B was prepared with acetonitrile/water/acetic acid (50:49.5:0.5, v/v/v). Both mobile phases $\mathrm{A}$ and $\mathrm{B}$ were degassed under vacuum at room temperature $\left(25^{\circ} \mathrm{C}\right)$ for $15 \mathrm{~min}$. All extracts were filtered by syringe (Kinesis, Redland, QLD, Australia) coupled with the $0.45 \mu \mathrm{m}$ syringe filter (Thermo Fisher Scientific Inc., Waltham, MA, USA) before transferring to vials for the HPLC. The injection volume was $6 \mu \mathrm{L}$ for each extract, and the flow rate was set at $0.8 \mathrm{~mL} / \mathrm{min}$. Elution conditions were as follows: 0 min with $10 \% \mathrm{~B}, 20 \mathrm{~min}$ with $25 \%$ B, 30 min with 35\% B, 40 min with 40\% B, 70 min with 55\% B, 75 min with 80\% B, 77 min with $100 \%$ B, 79 min with $100 \%$ B and $82-85$ min with isocratic $10 \% \mathrm{~B}$. The MS/MS peak identification was carried out in both negative and positive modes, and the mass spectra were obtained within the range of $m / z 50$ to 1300 amu. Further, MS/MS analyses were carried out in automatic mode with multiple collision energy (10, 15 and $30 \mathrm{eV})$ for fragmentation. The temperature of nitrogen gas was set at $300^{\circ} \mathrm{C}$, and the flow rate was set at $5 \mathrm{~L} / \mathrm{min}$. The temperature of sheath gas was set at $250^{\circ} \mathrm{C}$, and the flow rate was set at $11 \mathrm{~L} / \mathrm{min}$ with atomizing gas pressure 45 psi. The capillary and nozzle voltages were set at $3.5 \mathrm{kV}$ and $500 \mathrm{~V}$, respectively. Data collection and subsequent analysis were conducted using Agilent LC-ESI QTOF-MS/MS Mass Hunter Qualitative Software-B.03.01 (Agilent Technologies, Santa Clara, CA, USA).

\subsection{Quantification of Polyphenols via HPLC-PDA Analysis}

The quantification of phenolic compounds in the various sections (peel, pulp and seed) of custard apples was carried out by using the method of Ma et al. [26]. The detection for diverse phenolic constituents was carried out under three different wavelengths $(280,320$ and $370 \mathrm{~nm}$ ). The column and conditions followed the LC-MS/MS methodology, but the in- 
jection volume was $20 \mu \mathrm{L}$. A total of 10 targeted phenolic compounds were quantified in the present study, including 5 phenolic acids (protocatechuic acid, $p$-hydroxybenzoic acid, chlorogenic acid, syringic acid and $p$-coumaric acid) and 5 flavonoids (catechin, epicatechin, quercetin-3-glucoside, quercetin-3-rhamnoside and quercetin). Data collection and analysis were completed using Agilent LC-ESI-QTOF-MS/MS Mass Hunter Qualitative Software.

\subsection{Statistical Analysis}

All analyses were carried out in triplicate. The results are shown as mean \pm standard deviation (SD). Tukey's test in one-way analysis of variance (ANOVA) was performed using Minitab 18 Statistical software (Minitab Inc., State College, PA, USA) for the comparison of the concentration levels between samples' estimated phenolic content and antioxidant activities. $p<0.05$ was selected for the significance level for the Tukey's test.

\section{Results and Discussion}

\subsection{Phenolic Content Estimation (TFC, TFC, TTC)}

Custard apples, including atemoya and soursop, have been proven to have a considerable number of phenolic compounds $[27,28]$. The phenolic contents in this study were determined by TPC, TFC and TTC (Table 1).

In the TPC assay, the African Pride peel had the highest $(61.69 \pm 1.48 \mathrm{mg}$ GAE/g) phenolic content, followed by Pink's Mammoth and soursop peel. With regards to seed and pulp portions, African pride had the highest phenolic content $(1.40 \pm 0.07 \mathrm{mg}$ GAE/g and $3.81 \pm 0.17 \mathrm{mg} \mathrm{GAE} / \mathrm{g}$, respectively) when compared to the other varieties. Previously, Manochai et al. [5] reported values that range between 33.8 and $140.4 \mathrm{mg} \mathrm{GAE} / \mathrm{g}$, where the African pride showed higher values than those found in our study. The variation in the concentration of total phenolics in the custard apple might be due to the different concentrations of solvents used for extraction [24]. With respect to the TPC content, the peel extracts have significantly higher levels $(p<0.05)$ of total phenolic contents than the seeds and pulps. Sasidharan and Jayadev [29] reported that the higher phenolic content in the peel might be due to the pericarp being exposed to stress directly from the environment, unlike the seed and the pulp which are enclosed.

African Pride was found to have the most abundant TFC values for peels and pulps $(0.42 \pm 0.01 \mathrm{mg} \mathrm{GAE} / \mathrm{g}$ and $0.38 \pm 0.01 \mathrm{mg}$ GAE/g), while Pink's Mammoth exhibited the greatest value $(0.21 \pm 0.01 \mathrm{mg} \mathrm{GAE} / \mathrm{g})$ within seeds. Previously, Santos et al. [27] reported that the flavonoid content was the same as the TFC in African Pride and in Pink's Mammoth pulp.

To the best of our knowledge, only limited studies have been reported on TTC of custard apples. In the present study, the TTC was higher in peels of custard apples than in the pulp and seed. African Pride and Pink's Mammoth peel have significantly $(p<0.05)$ higher concentrations of tannins. Previously, the soursop pulp extracted with $50 \%$ methanol was found to have a higher value than that found in our study [27]. Lydia et al. [30] used various solvents (acetone, ethanol and water) for extraction and reported that the water extract had the lowest tannin content.

Overall, the African Pride peel variety of custard apple has higher total phenolics, flavonoids and tannin contents than the other two varieties, namely Pink's Mammoth and soursop, particularly in the peel and the seed. 
Table 1. Estimation of phenolic content and antioxidant potential of different custard apple samples.

\begin{tabular}{|c|c|c|c|c|c|c|c|c|c|}
\hline \multirow{2}{*}{ Assays } & \multicolumn{3}{|c|}{ Peel } & \multicolumn{3}{|c|}{ Seed } & \multicolumn{3}{|c|}{ Pulp } \\
\hline & African Pride & Pink's Mammoth & Soursop & African Pride & Pink's Mammoth & Soursop & African Pride & Pink's Mammoth & Soursop \\
\hline TPC (mg GAE/g) & $61.69 \pm 1.48^{a}$ & $19.37 \pm 0.27^{b}$ & $4.07 \pm 0.20^{c}$ & $1.40 \pm 0.07^{\mathrm{a}}$ & $1.10 \pm 0.04^{\mathrm{a}}$ & $0.39 \pm 0.01^{b}$ & $3.81 \pm 0.17^{\mathrm{a}}$ & $0.95 \pm 0.01^{\mathrm{b}}$ & $1.19 \pm 0.06^{b}$ \\
\hline $\mathrm{TFC}(\mathrm{mg} \mathrm{QE} / \mathrm{g})$ & $0.42 \pm 0.01^{\mathrm{a}}$ & $0.27 \pm 0.03^{b}$ & $0.06 \pm 0.01^{c}$ & $0.09 \pm 0.01^{b}$ & $0.21 \pm 0.01^{\mathrm{a}}$ & $0.09 \pm 0.01^{b}$ & $0.38 \pm 0.01^{\mathrm{a}}$ & $0.06 \pm 0.01^{b}$ & $0.04 \pm 0.01^{b}$ \\
\hline TAC (mg AAE/g) & $43.41 \pm 1.66^{\mathrm{a}}$ & $10.43 \pm 0.20^{b}$ & $0.83 \pm 0.01^{\mathrm{c}}$ & $2.48 \pm 0.05^{b}$ & $2.87 \pm 0.07^{\mathrm{a}}$ & $1.14 \pm 0.01^{\mathrm{c}}$ & $1.33 \pm 0.04^{\mathrm{a}}$ & $0.88 \pm 0.02^{b}$ & $0.32 \pm 0.01^{c}$ \\
\hline DPPH (mg AAE/g) & $1.87 \pm 0.09^{b}$ & $16.09 \pm 0.34^{\mathrm{a}}$ & $0.70 \pm 0.01^{c}$ & $1.39 \pm 0.08^{\mathrm{a}}$ & $0.68 \pm 0.02^{b}$ & $0.42 \pm 0.01^{\mathrm{c}}$ & $6.76 \pm 0.12^{b}$ & $13.75 \pm 0.67^{\mathrm{a}}$ & $0.03 \pm 0.01^{c}$ \\
\hline FRAP (mg AAE/g) & $3.60 \pm 0.14^{\mathrm{a}}$ & $0.43 \pm 0.01^{b}$ & $0.11 \pm 0.01^{b}$ & $0.34 \pm 0.01^{\mathrm{a}}$ & $0.03 \pm 0.01^{\mathrm{c}}$ & $0.14 \pm 0.01^{b}$ & $0.06 \pm 0.01^{\mathrm{a}}$ & $0.07 \pm 0.01^{\mathrm{a}}$ & $0.02 \pm 0.01^{\mathrm{a}}$ \\
\hline ABTS (mg AAE/g) & $127.67 \pm 4.60^{\mathrm{a}}$ & $33.40 \pm 0.93^{b}$ & $1.08 \pm 0.01^{\mathrm{c}}$ & $2.22 \pm 0.14^{\mathrm{a}}$ & $1.21 \pm 0.01^{\mathrm{b}}$ & $0.73 \pm 0.04^{c}$ & $7.02 \pm 0.15^{\mathrm{a}}$ & $1.86 \pm 0.01^{\mathrm{b}}$ & $0.49 \pm 0.01^{c}$ \\
\hline RPA (mg AAE/g) & $4.75 \pm 1.2^{\mathrm{b}}$ & $5.32 \pm 0.14^{\mathrm{a}}$ & $1.73 \pm 0.43^{c}$ & $5.63 \pm 0.24^{\mathrm{a}}$ & $4.96 \pm 0.01^{b}$ & $1.24 \pm 0.12^{c}$ & $6.47 \pm 0.03$ & $3.15 \pm 0.09$ & $1.45 \pm 0.03$ \\
\hline •OH-RSA (mg AAE/g) & $0.94 \pm 0.31^{b}$ & $1.23 \pm 0.25^{\mathrm{a}}$ & $0.93 \pm 0.39^{b}$ & $0.42 \pm 0.15^{b}$ & $0.15 \pm 0.09^{c}$ & $0.79 \pm 0.07^{\mathrm{a}}$ & $0.18 \pm 0.04^{b}$ & $1.14 \pm 0.04^{\mathrm{a}}$ & $0.97 \pm 0.07^{\mathrm{a}}$ \\
\hline FICA (mg EDTA/g) & $1.11 \pm 0.43^{b}$ & $3.17 \pm 0.18^{\mathrm{a}}$ & $0.75 \pm 0.21^{\mathrm{c}}$ & $2.14 \pm 0.14^{\mathrm{a}}$ & $1.58 \pm 0.12^{b}$ & $2.17 \pm 0.19^{a}$ & $0.98 \pm 0.09^{\mathrm{a}}$ & $0.13 \pm 0.01^{b}$ & $1.28 \pm 0.01^{\mathrm{a}}$ \\
\hline
\end{tabular}

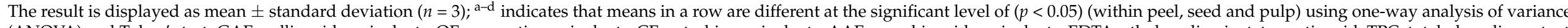

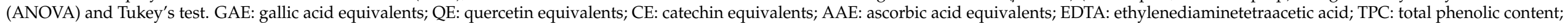

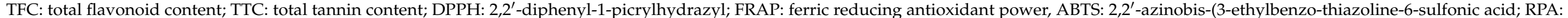
reducing power assay; $\bullet^{\bullet} \mathrm{OH}-\mathrm{RSA}$ : hydroxyl radical scavenging activity; FICA: ferrous ion chelating activity; TAC: total antioxidant content. 


\subsection{Antioxidant Activity (FRAP, DPPH, ABTS, RPA, ${ }^{\circ} \mathrm{OH}-\mathrm{RSA}$, FICA and TAC)}

In our current study, the antioxidant potential was estimated by FRAP, DPPH, ABTS, -OH-RSA, FICA, RPA and TAC assays, and the results are shown in Table 1.

In FRAP assay, the electron transfer method was used to measure the capacity of reducing $\mathrm{Fe}^{3+}$ to $\mathrm{Fe}^{2+}$ [31]. The African Pride peel $(3.60 \pm 0.14 \mathrm{mg} \mathrm{AAE} / \mathrm{g})$ and seed $(0.34 \pm 0.01 \mathrm{mg}$ $\mathrm{AAE} / \mathrm{g}$ ) had significantly higher antioxidant potential than the other two varieties, whereas no significant difference was observed within the pulps. Akomolafe and Ajayi [32] showed that the peel of soursop exhibited higher antioxidant potential than the pulp extract, which indicates that the peel extract has the ability to deactivate the initiation of lipid peroxidation in tissues.

In DPPH assay, the free radical scavenging activity was determined, which is most likely attributed to the phenolic compounds [33]. In our current study, Pink's Mammoth peel $(16.09 \pm 0.34 \mathrm{mg} \mathrm{AAE} / \mathrm{g})$ and pulp $(13.75 \pm 0.67 \mathrm{mg} \mathrm{AAE} / \mathrm{g})$ had higher antioxidant activity than African pride and soursop varieties. However, in the seed comparison, the African Pride had higher antioxidant potential. Previous studies also demonstrated that high antioxidant activity was exhibited in different portions of soursop grown in Panama $[34,35]$. In the ABTS assay, the antiradical scavenging activities are determined based on the hydrogen atom donating tendency of polyphenols [33]. Our present study showed that African Pride variety had a significantly higher $(p<0.05)$ value than Pink's Mammoth and soursop. Previously, Agu and Okolie [36] reported that the antioxidant activity might be due to the presence of phenolic compounds and acetogenins, including 15-acetyl guanacone, in soursop, and such compounds are abundant in annonaceous fruit.

In RPA, $\bullet$ OH-RSA and FICA assays, Pink's Mammoth peel had higher antioxidant potential than other varieties. In RPA, African Pride seed had the highest antioxidant potential, followed by pink mammoth and soursop. In ${ }^{\bullet} \mathrm{OH}-\mathrm{RSA}$ and FICA assays, soursop seed had high antioxidant activity compared to other varieties. African Pride, Pink's Mammoth and soursop pulps showed highly significant antioxidant activity in RPA, ${ }^{\bullet} \mathrm{OH}-\mathrm{RSA}$ and FICA assays. Previously, it was found that the reducing power of $A$. squamosa leaf extract is directly proportional to the concentration of the extract and ranged from 0.984 to $0.91 \mathrm{mg} / \mathrm{mL}$ [37]. Previously, Nandhakumar and Indumathi [38] showed that the ${ }^{\bullet} \mathrm{OH}$ scavenging activity was present in custard apple pulp and the range in aqueous extract was $13.27-74.65 \%$. Our study shows results similar to those of the previous studies. To our best knowledge, this is the first time that custard apple's antioxidant potential was analyzed through the FICA assay.

In the TAC assay, which was conducted by reducing molybdenum(VI) to molybdenum $(V)$ in the presence of phenolics, the peels of the custard apple varieties had generally higher values than pulps and seeds. The highest value was observed in African Pride peel (43.41 $\pm 1.66 \mathrm{mg} \mathrm{GAE} / \mathrm{g})$, followed by Pink's Mammoth peel $(10.43 \pm 0.20 \mathrm{mg}$ AAE/g) and Pink's Mammoth seed ( $2.87 \pm 0.07 \mathrm{mg} \mathrm{AAE} / \mathrm{g})$.

Overall, the African Pride variety exhibited higher antioxidant potential when compared with other varieties. Besides, the peels had higher antioxidant potential than the seeds and pulps. Serquiz et al. [24] reported that the peels and seeds of the custard apples, which constitute $40 \%$ of the fruit, go into food wastage and account for 10 tons of the inedible parts of the fruit discarded. Based on our current research, the inedible parts of the fruit can be utilized in the field of biotechnology and pharmacology [24,32].

\subsection{LC-ESI-QTOF-MS/MS Characterization}

The qualitative analysis of phenolic compounds from ethanolic extracts of custard apples was carried out by LC-ESI-QTOF-MS/MS. Phenolic compounds in nine custard apple samples were identified based on the retention time (RT), $m / z$ value and MS/MS spectra in both negative and positive ionization modes $\left([\mathrm{M}-\mathrm{H}]^{-} /[\mathrm{M}+\mathrm{H}]^{+}\right)$through Agilent LC-ESI-QTOF-MS /MS Mass Hunter Qualitative Software and Personal Compound Database and Library (PCDL). The library score (higher than 80) and mass error (less than $5 \mathrm{ppm}$ ) were chosen as the main criteria for the selection of compounds for further MS/MS analysis and $m / z$ characterization (Supplementary Materials, Figures S1-S3). In the present study, a total of 85 phenolic compounds were tentatively identified via LC-MS/MS, 
including 20 phenolic acids, 42 flavonoids, 4 stilbenes, 6 lignans and 13 other polyphenols, as shown in Table 2.

\subsubsection{Phenolic Acids}

There were four subclasses of phenolic acids identified in custard apple samples, namely hydroxybenzoic acid, hydroxycinnamic acids, hydroxyphenylacetic acids and hydroxyphenylpropanoic acids.

\section{Hydroxybenzoic Acid and Hydroxycinnamic Acid Derivatives}

Three hydroxybenzoic acids were detected in three out of nine custard apple samples. Compound 3 with $[\mathrm{M}-\mathrm{H}]^{-}$ion at $m / z 299.0778$ was only detected in African Pride seed and was tentatively characterized as 4-hydroxybenzoic acid 4-O-glucoside. The product ions at $m / z 255$ and $m / z 137$ from precursor ion correspond to the loss of $\mathrm{CO}_{2}(44 \mathrm{Da})$ and hexosyl moiety (162 Da), respectively [39]. Rosmarinic acid is a typical hydroxycinnamic derivative exclusively detected in African Pride peel, yielding the product ion at $\mathrm{m} / \mathrm{z}$ 179 , indicating the presence of caffeic acid ion. This compound was previously found in rosemary, basil and other Lamiaceae spices, as reported by Hossain et al. [40]. Compound $16\left([\mathrm{M}-\mathrm{H}]^{-}\right.$ion at $\left.m / z 179.0349\right)$ was tentatively characterized as caffeic acid, and the compound produced fragments at $m / z 143\left([\mathrm{M}-\mathrm{H}-36]^{-}\right.$, loss of two water molecules) and $m / z 133$ ([M $-\mathrm{H}-46]^{-}$, loss of $\mathrm{HCOOH}$ group), conforming to the fragmentation pattern of caffeic acid [41]. In a previous study, caffeic acid was likewise identified in the peel and seed of $A$. crassiflora in the research of Roesler et al. [42]. Through HPLC-DAD analysis, Nam et al. [43] quantified the concentration of caffeic acid in the tissues derived from another fruit from the Annonaceae family called pawpaw (Asimina triloba), and the value was around $21.23 \mathrm{mg} / 100 \mathrm{~g}$ in $80 \%$ methanol. 3-Sinapoylquinic acid $\left([\mathrm{M}-\mathrm{H}]^{-}\right.$ ion at $m / z$ 397.1143) was proposed for compound 6 detected in the pulp of African Pride and Pink's Mammoth, yielding fragment ions at $m / z 223$ (sinapic acid ion) and $m / z 179$ (sinapic acid - COO) [44]. Compound $17\left([\mathrm{M}-\mathrm{H}]^{-}\right.$at $m / z$ 326.1046) was characterized as $p$-coumaroyl tyrosine based on the comparison with previous study as the product ion was produced at $m / z 282$, corresponding to the loss of $44 \mathrm{Da}$ (a carbon dioxide molecule) from the precursor ion [45].

\subsubsection{Flavonoids}

Flavonoids are another important class of phenolic compounds and have an essential role in biological activities in plants. Based on the MS spectrum and data comparison with the literature, flavonoids accounted for nearly half of the total compounds that were identified and characterized, including the subclasses of anthocyanins, dihydrochalcones, dihydroflavonols, flavanols, flavanones, flavones, flavonols and isoflavonoids.

Anthocyanin, Dihydroflavonol and Flavonol Derivatives

Anthocyanidins, including cyanidin, pelargonidin, delphinidin, malvidin, petunidin and peonidin, are found in fruits and vegetables, and anthocyanins are the derivatives of anthocyanidins [46]. Compounds 24 and 25 were detected in both modes of ionization with precursor ions at $m / z 466.1116$ and $m / z$ 612.1694, respectively, and were tentatively identified as delphinidin 3-O-glucoside and cyanidin 3,5-O-diglucoside. Delphinidin 3$O$-glucoside had product ion at $m / z 303$ due to the loss of glucose, whereas cyanidin 3,5-O-diglucoside yielded $\mathrm{MS}^{2}$ ions at $m / z 449$ and $m / z 287$, corresponding to the loss of $\mathrm{C}_{6} \mathrm{H}_{10} \mathrm{O}_{5}$ and $2 \mathrm{C}_{6} \mathrm{H}_{10} \mathrm{O}_{5}[47,48]$. Petunidin 3-O-(6"'-acetyl-glucoside) (Compound 26 with $[\mathrm{M}+\mathrm{H}]^{+}$at $m / z$ 522.1373) was detected in the peel of soursop with product ion at $m / z$ 317 , indicating the loss of $204 \mathrm{Da}$ (acetyl and glucose moiety) from the precursor ion [47]. In addition, three other anthocyanidin derivatives were characterized as two cyanidin glucoside derivatives (Compounds 21 and 22) and one isopeonidin derivative (Compound 23) in the present research. 
Table 2. Characterization of phenolic compounds in custard apples by using LC-ESI-QTOF-MS/MS.

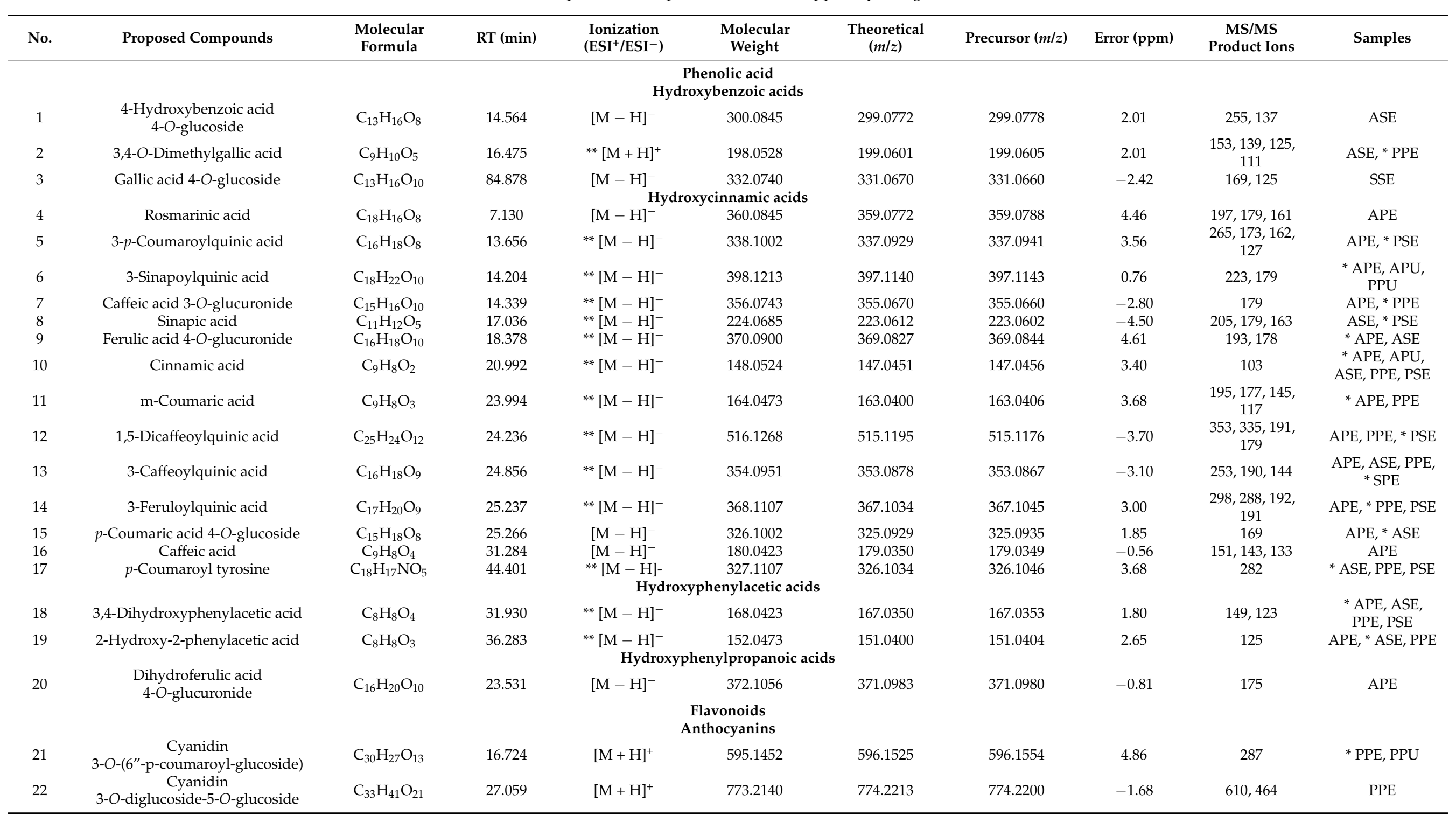


Table 2. Cont.

\begin{tabular}{|c|c|c|c|c|c|c|c|c|c|c|}
\hline No. & Proposed Compounds & $\begin{array}{l}\text { Molecular } \\
\text { Formula }\end{array}$ & RT (min) & $\begin{array}{l}\text { Ionization } \\
\left(\mathrm{ESI}^{+} / \mathrm{ESI}^{-}\right)\end{array}$ & $\begin{array}{l}\text { Molecular } \\
\text { Weight }\end{array}$ & $\begin{array}{l}\text { Theoretical } \\
\text { (m/z) }\end{array}$ & $\begin{array}{l}\text { Precursor } \\
(\mathrm{m} / \mathrm{z})\end{array}$ & $\begin{array}{l}\text { Error } \\
(\mathrm{ppm})\end{array}$ & $\begin{array}{c}\text { MS/MS } \\
\text { Product Ions }\end{array}$ & Samples \\
\hline 23 & Isopeonidin 3-O-arabinoside & $\mathrm{C}_{21} \mathrm{H}_{21} \mathrm{O}_{10}$ & 30.284 & $* *[\mathrm{M}+\mathrm{H}]^{+}$ & 433.1135 & 434.1208 & 434.1209 & 0.23 & $271,253,243$ & $\mathrm{PPE}, * \mathrm{SPE}$ \\
\hline 24 & Delphinidin 3-O-glucoside & $\mathrm{C}_{21} \mathrm{H}_{21} \mathrm{O}_{12}$ & 42.731 & ${ }^{* *}[\mathrm{M}+\mathrm{H}]^{+}$ & 465.1033 & 466.1106 & 466.1116 & 2.15 & 303 & $\begin{array}{l}\text { * APE, PPE, } \\
\text { PSE }\end{array}$ \\
\hline 25 & Cyanidin 3,5-O-diglucoside & $\mathrm{C}_{27} \mathrm{H}_{31} \mathrm{O}_{16}$ & 42.927 & ${ }^{* *}[\mathrm{M}+\mathrm{H}]^{+}$ & 611.1612 & 612.1685 & 612.1694 & 1.47 & 449,287 & $\begin{array}{l}\text { APE, ASE, * } \\
\text { PPE }\end{array}$ \\
\hline 26 & $\begin{array}{c}\text { Petunidin } \\
3-O-\left(6^{\prime \prime} \text {-acetyl-glucoside }\right)\end{array}$ & $\mathrm{C}_{24} \mathrm{H}_{25} \mathrm{O}_{13}$ & 59.402 & {$[\mathrm{M}+\mathrm{H}]^{+}$} & 521.1295 & 522.1368 & 522.1373 & 0.96 & 317 & SPE \\
\hline \multicolumn{11}{|c|}{ Dihydrochalcones } \\
\hline 27 & Phloridzin & $\mathrm{C}_{21} \mathrm{H}_{24} \mathrm{O}_{10}$ & 17.951 & ${ }^{* *}[\mathrm{M}-\mathrm{H}]^{-}$ & 436.1369 & 435.1296 & 435.1289 & -1.61 & 273 & $\begin{array}{l}\text { APE, PPE, } \\
\text { *PPU }\end{array}$ \\
\hline 28 & $\begin{array}{l}\text { 3-Hydroxyphloretin } \\
2^{\prime} \text {-O-glucoside }\end{array}$ & $\mathrm{C}_{21} \mathrm{H}_{24} \mathrm{O}_{11}$ & 22.371 & ${ }^{* *}[\mathrm{M}-\mathrm{H}]^{-}$ & 452.1319 & 451.1246 & 451.1247 & 0.20 & 289,273 & $\begin{array}{l}\text { APE, ASE, * } \\
\text { PPE, PSE }\end{array}$ \\
\hline 29 & Dihydroquercetin & $\mathrm{C}_{15} \mathrm{H}_{12} \mathrm{O}_{7}$ & 44.268 & {$[\mathrm{M}-\mathrm{H}]^{-}$} & $\begin{array}{l}\text { roflavonols } \\
304.0583 \\
\text { vonols }\end{array}$ & 303.0510 & 303.0520 & 3.30 & 151,125 & $\mathrm{APE}, * \mathrm{ASE}$ \\
\hline 30 & Procyanidin trimer $\mathrm{C} 1$ & $\mathrm{C}_{45} \mathrm{H}_{38} \mathrm{O}_{18}$ & 23.564 & ${ }^{* *}[\mathrm{M}-\mathrm{H}]^{-}$ & 866.2058 & 865.1985 & 865.1992 & 0.81 & $739,713,695$ & $\begin{array}{l}\text { * APE, APU, } \\
\text { ASE, PPE, } \\
\text { PPU, PSE }\end{array}$ \\
\hline 31 & Cinnamtannin A2 & $\mathrm{C}_{60} \mathrm{H}_{50} \mathrm{O}_{24}$ & 23.696 & ${ }^{* *}[\mathrm{M}-\mathrm{H}]^{-}$ & 1154.2692 & 1153.2620 & 1153.2600 & -1.91 & 1027,1001 & $\begin{array}{l}\text { * APE, ASE, } \\
\text { PPE, PPU }\end{array}$ \\
\hline 32 & Procyanidin dimer B1 & $\mathrm{C}_{30} \mathrm{H}_{26} \mathrm{O}_{12}$ & 28.103 & ${ }^{* *}[\mathrm{M}-\mathrm{H}]^{-}$ & 578.1424 & 577.1351 & 577.1324 & -4.68 & 451 & $\begin{array}{l}\text { * APE, ASE, } \\
\text { PPE, PPU, PSE }\end{array}$ \\
\hline 33 & (-)-Epicatechin & $\mathrm{C}_{15} \mathrm{H}_{14} \mathrm{O}_{6}$ & 31.218 & ${ }^{* *}[\mathrm{M}-\mathrm{H}]^{-}$ & 290.0790 & 289.0717 & 289.0715 & -0.69 & $245,205,179$ & $\begin{array}{l}\text { * APE, ASE, } \\
\text { PPU, PSE }\end{array}$ \\
\hline 34 & (-)-Epigallocatechin & $\mathrm{C}_{15} \mathrm{H}_{14} \mathrm{O}_{7}$ & 84.626 & $* *[\mathrm{M}+\mathrm{H}]^{+}$ & $\begin{array}{l}306.0740 \\
\text { vanones }\end{array}$ & 307.0813 & 307.0815 & 0.65 & 167,137 & $\mathrm{ASE}, * \mathrm{PSE}$ \\
\hline 35 & Eriocitrin & $\mathrm{C}_{27} \mathrm{H}_{32} \mathrm{O}_{15}$ & 39.899 & ${ }^{* *}[\mathrm{M}-\mathrm{H}]^{-}$ & 596.1741 & 595.1668 & 595.1684 & 2.69 & 431,287 & $\begin{array}{l}\text { * APE, ASE, } \\
\text { PPE, PPU, PSE }\end{array}$ \\
\hline 36 & Naringin $4^{\prime}$-O-glucoside & $\mathrm{C}_{33} \mathrm{H}_{42} \mathrm{O}_{19}$ & 53.036 & {$[\mathrm{M}-\mathrm{H}]^{-}$} & $\begin{array}{l}742.2320 \\
\text { avones }\end{array}$ & 741.2247 & 741.2251 & 0.54 & 433,271 & APE \\
\hline 37 & Apigenin 7-O-glucuronide & $\mathrm{C}_{21} \mathrm{H}_{18} \mathrm{O}_{11}$ & 20.967 & {$[\mathrm{M}+\mathrm{H}]^{+}$} & 446.0849 & 447.0922 & 447.0910 & -2.68 & 271,253 & $\begin{array}{l}\text { * APE, PPE, } \\
\text { PPU }\end{array}$ \\
\hline 38 & Isorhoifolin & $\mathrm{C}_{27} \mathrm{H}_{30} \mathrm{O}_{14}$ & 26.135 & {$[\mathrm{M}-\mathrm{H}]^{-}$} & 578.1636 & 577.1563 & 577.1588 & 4.33 & $\begin{array}{c}433,415,397 \\
271\end{array}$ & PPU \\
\hline 39 & Apigenin 6,8-di-C-glucoside & $\mathrm{C}_{27} \mathrm{H}_{30} \mathrm{O}_{15}$ & 42.844 & ${ }^{* *}[\mathrm{M}-\mathrm{H}]^{-}$ & 594.1585 & 593.1512 & 593.1535 & 3.88 & $575,503,473$ & $\begin{array}{l}\mathrm{APE},{ }^{*} \mathrm{ASE} \\
\mathrm{PPE}, \mathrm{PSE}\end{array}$ \\
\hline
\end{tabular}


Table 2. Cont.

\begin{tabular}{|c|c|c|c|c|c|c|c|c|c|c|}
\hline No. & Proposed Compounds & $\begin{array}{l}\text { Molecular } \\
\text { Formula }\end{array}$ & RT (min) & $\begin{array}{l}\text { Ionization } \\
\left(\mathrm{ESI}^{+} / \mathrm{ESI}^{-}\right)\end{array}$ & $\begin{array}{l}\text { Molecular } \\
\text { Weight }\end{array}$ & $\begin{array}{l}\text { Theoretical } \\
\qquad(\mathrm{m} / \mathrm{z})\end{array}$ & $\begin{array}{l}\text { Precursor } \\
\quad(m / z)\end{array}$ & $\begin{array}{r}\text { Error } \\
(\mathrm{ppm})\end{array}$ & $\begin{array}{c}\text { MS/MS } \\
\text { Product Ions }\end{array}$ & Samples \\
\hline 40 & Apigenin 6-C-glucoside & $\mathrm{C}_{21} \mathrm{H}_{20} \mathrm{O}_{10}$ & 55.256 & {$[\mathrm{M}-\mathrm{H}]^{+}$} & 432.1056 & 431.0983 & 431.0984 & 0.20 & $413,341,311$ & PPE \\
\hline 41 & $\begin{array}{l}\text { 6-Hydroxyluteolin } \\
\text { 7-O-rhamnoside }\end{array}$ & $\mathrm{C}_{21} \mathrm{H}_{20} \mathrm{O}_{11}$ & 57.850 & {$[\mathrm{M}-\mathrm{H}]^{-}$} & 448.1006 & 447.0933 & 447.0931 & -0.45 & 285 & $\mathrm{ASE}, * \mathrm{PPE}$ \\
\hline \multicolumn{11}{|c|}{ Flavonols } \\
\hline 42 & Myricetin 3-O-arabinoside & $\mathrm{C}_{20} \mathrm{H}_{18} \mathrm{O}_{12}$ & 10.012 & $* *[\mathrm{M}-\mathrm{H}]^{-}$ & 450.0798 & 449.0725 & 449.0722 & -0.67 & 316 & ${ }^{*} \mathrm{APU}, \mathrm{PSE}$ \\
\hline 43 & Myricetin 3-O-rutinoside & $\mathrm{C}_{27} \mathrm{H}_{30} \mathrm{O}_{17}$ & 32.049 & {$[\mathrm{M}-\mathrm{H}]^{-}$} & 626.1483 & 625.1410 & 625.1382 & -4.50 & 301 & PSE \\
\hline 44 & Myricetin 3-O-glucoside & $\mathrm{C}_{21} \mathrm{H}_{20} \mathrm{O}_{13}$ & 34.017 & {$[\mathrm{M}-\mathrm{H}]^{-}$} & 480.0904 & 479.0831 & 479.0833 & 0.40 & 317 & APU \\
\hline 46 & $\begin{array}{c}\text { Quercetin } \\
\text { 3-O-xylosyl-glucuronide }\end{array}$ & $\mathrm{C}_{26} \mathrm{H}_{26} \mathrm{O}_{17}$ & 39.195 & {$[\mathrm{M}+\mathrm{H}]^{+}$} & 610.1170 & 611.1243 & 611.1241 & -0.33 & $\begin{array}{c}479,303,285 \\
239\end{array}$ & ASE \\
\hline 47 & Quercetin 3-O-arabinoside & $\mathrm{C}_{20} \mathrm{H}_{18} \mathrm{O}_{11}$ & 42.798 & {$[\mathrm{M}-\mathrm{H}]^{-}$} & 434.0849 & 433.0776 & 433.0772 & -0.90 & 301 & * ASE, PPE \\
\hline 48 & Kaempferol 3,7-O-diglucoside & $\mathrm{C}_{27} \mathrm{H}_{30} \mathrm{O}_{16}$ & 43.092 & {$[\mathrm{M}-\mathrm{H}]^{-}$} & 610.1534 & 609.1461 & 609.1478 & 2.79 & 449,287 & $\mathrm{APE}, * \mathrm{ASE}$ \\
\hline 49 & $\begin{array}{l}\text { Kaempferol 3-O-glucosyl- } \\
\text { rhamnosyl-galactoside }\end{array}$ & $\mathrm{C}_{33} \mathrm{H}_{40} \mathrm{O}_{20}$ & 43.311 & {$[\mathrm{M}-\mathrm{H}]^{-}$} & 756.2113 & 755.2040 & 755.2038 & -0.26 & 285 & * APE, ASE \\
\hline 50 & Myricetin 3-O-rhamnoside & $\mathrm{C}_{21} \mathrm{H}_{20} \mathrm{O}_{12}$ & 45.428 & ${ }^{* *}[\mathrm{M}-\mathrm{H}]^{-}$ & 464.0955 & 463.0882 & 463.0877 & -1.08 & $316,271,221$ & $\begin{array}{l}\text { * ASE, PPE, } \\
\text { PSE }\end{array}$ \\
\hline 52 & 3-Methoxysinensetin & $\mathrm{C}_{21} \mathrm{H}_{22} \mathrm{O}_{8}$ & 66.632 & {$[\mathrm{M}+\mathrm{H}]^{+}$} & 402.1315 & 403.1388 & 403.1380 & -1.98 & $\begin{array}{l}388,373,355 \\
\quad 327\end{array}$ & $\mathrm{APE}$ \\
\hline \multicolumn{11}{|c|}{ Isoflavonoids } \\
\hline 53 & 6"-O-Acetyldaidzin & $\mathrm{C}_{23} \mathrm{H}_{22} \mathrm{O}_{10}$ & 4.413 & {$[\mathrm{M}-\mathrm{H}]^{-}$} & 458.1213 & 457.1140 & 457.1125 & -3.30 & 221 & PPE \\
\hline 54 & Sativanone & $\mathrm{C}_{17} \mathrm{H}_{16} \mathrm{O}_{5}$ & 9.250 & {$[\mathrm{M}-\mathrm{H}]^{-}$} & 300.0998 & 299.0925 & 299.0914 & -3.68 & $284,269,225$ & $\mathrm{APE}$ \\
\hline 55 & Dihydrobiochanin A & $\mathrm{C}_{16} \mathrm{H}_{14} \mathrm{O}_{5}$ & 11.267 & {$[\mathrm{M}+\mathrm{H}]^{+}$} & 286.0841 & 287.0914 & 287.0905 & -3.13 & 270 & PSE \\
\hline 56 & 3'-O-Methylviolanone & $\mathrm{C}_{18} \mathrm{H}_{18} \mathrm{O}_{6}$ & 16.973 & {$[\mathrm{M}-\mathrm{H}]^{-}$} & 330.1103 & 329.1030 & 329.1030 & 0.00 & $\begin{array}{l}314,299,284 \\
256\end{array}$ & PPU \\
\hline 57 & Violanone & $\mathrm{C}_{17} \mathrm{H}_{16} \mathrm{O}_{6}$ & 20.267 & {$[\mathrm{M}-\mathrm{H}]^{-}$} & 316.0947 & 315.0874 & 315.0868 & -1.90 & $300,285,135$ & PPE \\
\hline 58 & $3^{\prime}, 4^{\prime}, 7$-Trihydroxyisoflavanone & $\mathrm{C}_{15} \mathrm{H}_{12} \mathrm{O}_{5}$ & 24.011 & ${ }^{* *}[\mathrm{M}-\mathrm{H}]^{-}$ & 272.0685 & 271.0612 & 271.0623 & 4.06 & $\begin{array}{l}177,151,119 \\
107\end{array}$ & $\begin{array}{l}\text { * APE, PPE, } \\
\text { PPU }\end{array}$ \\
\hline 59 & $\begin{array}{c}5,6,7,3^{\prime}, 4^{\prime}- \\
\text { Pentahydroxyisoflavone }\end{array}$ & $\mathrm{C}_{15} \mathrm{H}_{10} \mathrm{O}_{7}$ & 39.465 & ${ }^{* *}[\mathrm{M}+\mathrm{H}]^{+}$ & 302.0427 & 303.0500 & 303.0491 & -3.00 & 285,257 & $\begin{array}{l}\text { * APE, PPE, } \\
\text { PSE }\end{array}$ \\
\hline 60 & 3'-Hydroxygenistein & $\mathrm{C}_{15} \mathrm{H}_{10} \mathrm{O}_{6}$ & 42.565 & {$[\mathrm{M}+\mathrm{H}]^{+}$} & 286.0477 & 287.0550 & 287.0560 & 3.48 & 269,259 & APE \\
\hline 61 & 6"-O-Acetylglycitin & $\mathrm{C}_{24} \mathrm{H}_{24} \mathrm{O}_{11}$ & 43.656 & {$[\mathrm{M}+\mathrm{H}]^{+}$} & 488.1319 & 489.1392 & 489.1413 & 4.29 & 285,270 & PPE \\
\hline 62 & 6"-O-Malonyldaidzin & $\mathrm{C}_{24} \mathrm{H}_{22} \mathrm{O}_{12}$ & 45.321 & {$[\mathrm{M}+\mathrm{H}]^{+}$} & 502.1111 & 503.1184 & 503.1189 & 0.99 & 255 & PSE \\
\hline
\end{tabular}


Table 2. Cont.

\begin{tabular}{|c|c|c|c|c|c|c|c|c|c|c|}
\hline No. & Proposed Compounds & $\begin{array}{l}\text { Molecular } \\
\text { Formula }\end{array}$ & RT (min) & $\begin{array}{l}\text { Ionization } \\
\left(\mathrm{ESI}^{+} / \mathrm{ESI}^{-}\right)\end{array}$ & $\begin{array}{c}\text { Molecular } \\
\text { Weight }\end{array}$ & $\begin{array}{l}\text { Theoretical } \\
(\mathrm{m} / \mathrm{z})\end{array}$ & $\begin{array}{l}\text { Precursor } \\
\quad(\mathrm{m} / \mathrm{z})\end{array}$ & $\begin{array}{r}\text { Error } \\
(\mathrm{ppm})\end{array}$ & $\begin{array}{c}\text { MS/MS } \\
\text { Product Ions }\end{array}$ & Samples \\
\hline \multicolumn{11}{|c|}{ Lignans } \\
\hline 63 & Episesamin & $\mathrm{C}_{20} \mathrm{H}_{18} \mathrm{O}_{6}$ & 20.860 & ${ }^{* *}[\mathrm{M}-\mathrm{H}]^{-}$ & 354.1103 & 353.1030 & 353.1029 & -0.28 & 338,163 & * ASE, PPU \\
\hline 64 & Matairesinol & $\mathrm{C}_{20} \mathrm{H}_{22} \mathrm{O}_{6}$ & 24.760 & {$[\mathrm{M}-\mathrm{H}]^{-}$} & 358.1416 & 357.1343 & 357.1343 & 0.00 & $\begin{array}{c}342,327,313, \\
221\end{array}$ & PPU \\
\hline 65 & Enterolactone & $\mathrm{C}_{18} \mathrm{H}_{18} \mathrm{O}_{4}$ & 35.010 & {$[\mathrm{M}+\mathrm{H}]^{+}$} & 298.1205 & 299.1278 & 299.1292 & 4.68 & 281,165 & ${ }^{*}$ PPE, PSE \\
\hline 66 & Schisanhenol & $\mathrm{C}_{23} \mathrm{H}_{30} \mathrm{O}_{6}$ & 35.468 & {$[\mathrm{M}+\mathrm{H}]^{+}$} & 402.2042 & 403.2115 & 403.2128 & 3.22 & $385,354,331$ & SPE \\
\hline 67 & Schisandrin & $\mathrm{C}_{24} \mathrm{H}_{32} \mathrm{O}_{7}$ & 52.095 & {$[\mathrm{M}+\mathrm{H}]^{+}$} & 432.2148 & 433.2221 & 433.2230 & 2.08 & $415,384,361$ & PSE \\
\hline \multicolumn{11}{|c|}{ Stilbenes } \\
\hline 69 & Piceatannol 3-O-glucoside & $\mathrm{C}_{20} \mathrm{H}_{22} \mathrm{O}_{9}$ & 8.335 & $* *[\mathrm{M}-\mathrm{H}]^{-}$ & 406.1264 & 405.1191 & 405.1172 & -4.69 & 243 & * ASE, PPU \\
\hline 70 & $\begin{array}{c}\text { 4'-Hydroxy-3,4,5- } \\
\text { trimethoxystilbene }\end{array}$ & $\mathrm{C}_{17} \mathrm{H}_{18} \mathrm{O}_{4}$ & 29.576 & {$[\mathrm{M}+\mathrm{H}]^{+}$} & 286.1205 & 287.1278 & 287.1270 & -2.79 & $271,241,225$ & $\begin{array}{l}\text { *APU, ASE, } \\
\text { PPE, PSE }\end{array}$ \\
\hline 71 & Resveratrol & $\mathrm{C}_{14} \mathrm{H}_{12} \mathrm{O}_{3}$ & 31.267 & {$[\mathrm{M}-\mathrm{H}]^{-}$} & 228.0786 & 227.0713 & 227.0709 & -1.76 & $185,157,143$ & APE \\
\hline 72 & $\begin{array}{l}\text { 3'-Hydroxy-3,4,5,4'- } \\
\text { tetramethoxystilbene }\end{array}$ & $\mathrm{C}_{17} \mathrm{H}_{18} \mathrm{O}_{5}$ & 43.904 & {$[\mathrm{M}+\mathrm{H}]^{+}$} & 302.1154 & 303.1227 & 303.1221 & -1.98 & $\begin{array}{c}229,201,187 \\
175\end{array}$ & * PPE, PPU \\
\hline \multicolumn{11}{|c|}{$\begin{array}{l}\text { Other polyphenols } \\
\text { Curcuminoids }\end{array}$} \\
\hline \multicolumn{11}{|c|}{ Furanocoumarins } \\
\hline 74 & Isopimpinellin & $\mathrm{C}_{13} \mathrm{H}_{10} \mathrm{O}_{5}$ & 17.193 & {$[\mathrm{M}+\mathrm{H}]^{+}$} & 246.0528 & 247.0601 & 247.0595 & -2.43 & $\begin{array}{c}232,217,205 \\
203\end{array}$ & $\begin{array}{l}\text { APE, APU, } \\
\text { PPE, *PPU, } \\
\text { PSE }\end{array}$ \\
\hline \multicolumn{11}{|c|}{ Hydroxybenzaldehydes } \\
\hline 75 & p-Anisaldehyde & $\mathrm{C}_{8} \mathrm{H}_{8} \mathrm{O}_{2}$ & 6.041 & $* *[\mathrm{M}+\mathrm{H}]^{+}$ & 136.0524 & 137.0597 & 137.0601 & 2.92 & 122,109 & $\begin{array}{l}\text { APE, ASE, * } \\
\text { PPE, PPU, PSE }\end{array}$ \\
\hline 76 & 4-Hydroxybenzaldehyde & $\mathrm{C}_{7} \mathrm{H}_{6} \mathrm{O}_{2}$ & 30.767 & ${ }^{* *}[\mathrm{M}-\mathrm{H}]^{-}$ & 122.0368 & 121.0295 & 121.0293 & -1.65 & 92,77 & $\begin{array}{l}\mathrm{APE}, * \mathrm{ASE} \\
\mathrm{PPE}, \mathrm{PPU}\end{array}$ \\
\hline \multicolumn{11}{|c|}{ Hydroxybenzoketones } \\
\hline 77 & Scopoletin & $\mathrm{C}_{10} \mathrm{H}_{8} \mathrm{O}_{4}$ & 7.554 & {$[\mathrm{M}-\mathrm{H}]^{-}$} & 192.0423 & 191.0350 & 191.0347 & -1.60 & 176,147 & $\begin{array}{l}\text { APE, APU, * } \\
\text { PPE, PSE }\end{array}$ \\
\hline 78 & $\begin{array}{l}\text { 2,3-Dihydroxy-1- } \\
\text { guaiacylpropanone }\end{array}$ & $\mathrm{C}_{10} \mathrm{H}_{12} \mathrm{O}_{5}$ & 16.950 & ${ }^{* *}[\mathrm{M}-\mathrm{H}]^{-}$ & 212.0685 & 211.0612 & 211.0605 & -3.32 & $\begin{array}{c}167,123,105 \\
93\end{array}$ & $\begin{array}{l}\mathrm{APE},{ }^{*} \mathrm{ASE} \\
\mathrm{PPE}\end{array}$ \\
\hline 79 & Coumarin & $\mathrm{C}_{9} \mathrm{H}_{6} \mathrm{O}_{2}$ & 63.127 & {$[\mathrm{M}+\mathrm{H}]^{+}$} & 146.0368 & 147.0441 & 147.0442 & 0.68 & 103,91 & $\begin{array}{l}\text { PPE, PPU, * } \\
\text { PSE }\end{array}$ \\
\hline
\end{tabular}


Table 2. Cont.

\begin{tabular}{|c|c|c|c|c|c|c|c|c|c|c|}
\hline No. & Proposed Compounds & $\begin{array}{l}\text { Molecular } \\
\text { Formula }\end{array}$ & RT (min) & $\begin{array}{l}\text { Ionization } \\
\left(\mathrm{ESI}^{+} / \mathrm{ESI}^{-}\right)\end{array}$ & $\begin{array}{l}\text { Molecular } \\
\text { Weight }\end{array}$ & $\begin{array}{l}\text { Theoretical } \\
\text { (m/z) }\end{array}$ & $\begin{array}{l}\text { Precursor } \\
\quad(\mathrm{m} / \mathrm{z})\end{array}$ & $\begin{array}{r}\text { Error } \\
(\mathrm{ppm})\end{array}$ & $\begin{array}{c}\text { MS/MS } \\
\text { Product Ions }\end{array}$ & Samples \\
\hline \multicolumn{11}{|c|}{ Hydroxyphenylpropenes } \\
\hline 80 & $\begin{array}{l}\text { 2-Methoxy-5-prop-1- } \\
\text { envlphenol }\end{array}$ & $\mathrm{C}_{10} \mathrm{H}_{12} \mathrm{O}_{2}$ & 8.404 & {$[\mathrm{M}+\mathrm{H}]^{+}$} & 164.0837 & 165.0910 & 165.0910 & 0.00 & $\begin{array}{c}149,137,133, \\
124\end{array}$ & * SPE, SPU \\
\hline \multicolumn{11}{|c|}{ Phenolic terpenes } \\
\hline 81 & Rosmanol & $\mathrm{C}_{20} \mathrm{H}_{26} \mathrm{O}_{5}$ & 34.541 & {$[\mathrm{M}+\mathrm{H}]^{+}$} & 346.1780 & 347.1853 & 347.1844 & -2.59 & 301,231 & PPU, * SPE \\
\hline 82 & Carnosic acid & $\mathrm{C}_{20} \mathrm{H}_{28} \mathrm{O}_{4}$ & 80.860 & {$[\mathrm{M}-\mathrm{H}]^{-}$} & $\begin{array}{l}332.1988 \\
\text { Tyrosols }\end{array}$ & 331.1915 & 331.1922 & 2.10 & 287,269 & $\mathrm{ASE}, * \mathrm{PSE}$ \\
\hline 83 & Hydroxytyrosol 4-O-glucoside & $\mathrm{C}_{14} \mathrm{H}_{20} \mathrm{O}_{8}$ & 14.283 & $* *[\mathrm{M}-\mathrm{H}]^{-}$ & $\begin{array}{l}\text { Tyrosols } \\
\quad 316.1158\end{array}$ & 315.1085 & 315.1098 & 4.13 & 153,123 & \multirow{2}{*}{$\begin{array}{c}\mathrm{ASE},{ }^{*} \mathrm{PSE} \\
\mathrm{APE},{ }^{*} \mathrm{PPE}, \\
\mathrm{PSE}\end{array}$} \\
\hline 84 & 3,4-DHPEA-AC & $\mathrm{C}_{10} \mathrm{H}_{12} \mathrm{O}_{4}$ & 19.522 & {$[\mathrm{M}-\mathrm{H}]^{-}$} & 196.0736 & 195.0663 & 195.0667 & 2.10 & 135 & \\
\hline 85 & Demethyloleuropein & $\mathrm{C}_{24} \mathrm{H}_{30} \mathrm{O}_{13}$ & 38.557 & $* *[\mathrm{M}-\mathrm{H}]^{-}$ & 526.1686 & 525.1613 & 525.1627 & 2.67 & 495 & ${ }^{*} \mathrm{APE}, \mathrm{SPE}$ \\
\hline
\end{tabular}

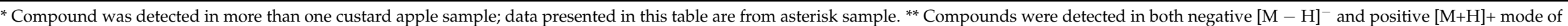

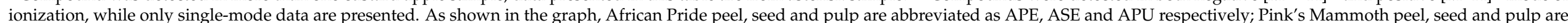
abbreviated as PPE, PSE and PPU respectively; soursop peel, seed and pulp are abbreviated as SPE, SSE and SPU, respectively. 
Dihydroquercetin was the only dihydroflavonol identified in African Pride peel and seed with the typical fragment ion at $m / z 151$ formed from the cleavage of the flavonoid $\mathrm{C}$ ring. The product ion was consistent with that found in a previous study in which dihydroquercetin was characterized in an investigation of the phenolic compounds in custard apple pulp by adopting UPLC-ESI-MS/MS [49].

Compound 33 with $[\mathrm{M}-\mathrm{H}]^{-}$at $m / z 289.0715$ with fragment ions at $m / z 245, m / z$ 205 and $m / z 179$ due to the loss of $\mathrm{CO}_{2}$ (44 Da), flavonoid A ring (84 Da) and flavonoid B ring (110 Da) was characterized as (-)-epicatechin [39]. The research of Huang et al. [50] reported the presence of (-)-epicatechin with identical ionization mode $\left(\mathrm{ESI}^{-}\right)$with precursor ion at $m / z$ 289. Furthermore, the finding in the research of Baskaran et al. [49] was also in accordance with our outcome, as they reported the same product ions for the compound found in the pulp portion. Another identified common compound (Compound 34 showing $[\mathrm{M}+\mathrm{H}]^{+}$at $m / z$ 307.0815) was (-)-epigallocatechin based on MS/MS ions at $m / z$ 167 and $m / z$ 137, corresponding to the RDA fragmentation pattern [51]. Similarly, Baskaran et al. [49] found the presence of epigallocatechin in bound form but in pulp of custard apple rather than the seed as found in the present research. Procyanidin dimer B1 identified at $[\mathrm{M}-\mathrm{H}]^{-}$with $\mathrm{m} / \mathrm{z} 577.1324$ was tentatively found in both atemoya peels in our research. The study of Justino et al. [52] reported procyanidin B2 rather than procyanidin B1 in Annona crassiflora peel. The findings of Huang et al. [50] explained this variability in their result since two diverse $B$ types procyanidin dimers were identified in the extract of Annona squamosa peel, and the $m / z$ values (577 and 579) in negative mode corresponded to the ones reported for procyanidin dimer B2 and procyanidin dimer B1, respectively. Additionally, the results of our study were consistent with those of Justino et al. [52] in the detection of procyanidin trimer $\mathrm{C} 1$ in the peel of custard apple samples, while the present study further suggests the presence of this specific compound in the pulp and seed of custard apple.

Flavanone, Flavone and Flavonol Derivatives

For flavanones, all of the constituents shown in Table 2 were reported in custard apple for the first time. Compound 36 detected in negative mode with precursor ion at $\mathrm{m} / \mathrm{z}$ 741.2251 was identified in African Pride peel and confirmed as naringin $4^{\prime}$-O-glucoside with product ions at $m / z 433$ and $m / z 271$ [53]. Eriocitrin, a flavanone found in an abundance in citrus fruits [54], was characterized with product ions at $m / z 431$ and $m / z 287$ in the negative ionization mode, representing the loss of rhamnose moiety, water and glucose [55].

In terms of flavones, five diverse compounds were characterized in custard apple samples. Compound 37 with $[\mathrm{M}-\mathrm{H}]^{-m / z}$ at 447.0910 was characterized as apigenin 7-O-glucuronide through the comparison with a previous study, with fragment ions at $m / z 271$ and $m / z 253$ due to the loss of a glucuronic acid moiety (176 Da) and a water molecule [56]. The presence of product ions at $m / z 433$ and $m / z 271$ in negative mode, due to the loss of rhamnose and further cleavage of glucose, identified compound 38 (isorhoifolin), which was uniquely detected in Pink's Mammoth pulp [55]. Compounds 39 and 40 were characterized as apigenin 6,8-di-C-glucoside and apigenin 6-C-glucoside, respectively. Previously, Santos and Salatino [57] reported apigenin 6-C-glucoside as one of the foliar flavones of Annonaceae from Brazil, while Kadam et al. [58] illustrated that this compound is widely distributed in medicinal plants and possesses high potential for pharmacological use due to antioxidant and anti-inflammatory properties [59].

\section{Flavonol Derivatives}

Myricetin, quercetin and kaempferol derivatives have been characterized in custard apple. Myricetin 3-O-arabinoside (Compound 42), [M - H] ${ }^{-}$ion at $m / z$ 449.0722, was tentatively identified in African Pride pulp and Pink's Mammoth seed. The identification was verified by the major produced product ion at $m / z 316$, indicating the loss of $133 \mathrm{Da}$ (pentose moiety). Previously, this compound was characterized in cranberry cultivars via UPLC-IM-HRMS [60]. Compounds 43, 44 and 50 were also identified as myricetin 3-O derivatives in the present research and were assigned as myricetin 3-O-rutinoside, 
myricetin 3-O-glucoside and myricetin 3-O-rhamnoside, respectively. With respect to quercetin derivatives, all three derivatives could be tentatively identified in African Pride seed. Compound 45 showing precursor ion at $m / z 743.2060$ was proposed as quercetin 3-Oxylosyl-rutinoside, with product ions at $m / z 479$ and $m / z 317$ due to the loss of two pentoses and additional loss of a hexose [61]. The identification of quercetin 3-O-xylosyl-glucuronide was confirmed by the characteristic fragment ion at $m / z 303$ produced by the cleavage of glucuronide. The $\mathrm{MS}^{2}$ spectrum had fragment ions at $m / z 285\left[\mathrm{M}+\mathrm{H}\right.$-glucuronide- $\left.\mathrm{H}_{2} \mathrm{O}\right]$ and $m / z 239\left[\mathrm{M}+\mathrm{H}\right.$-glucuronide-2 $\mathrm{H}_{2} \mathrm{O}-\mathrm{CO}$ ], further supporting the characterization [62]. Kaempferol 3,7-O-diglucoside and kaempferol 3-O-glucosyl-rhamnosyl-galactoside showing $[\mathrm{M}-\mathrm{H}]^{-}$ion at $m / z 609.1478$ and $m / z$ 755.2038, respectively, were two kaempferol derivatives detected in African Pride peel and seed. The former flavonol gave product ions at $m / z 447$ and $m / z 285$ due to the loss of glucose (162 Da) and two glucoses (314 Da), while the latter flavonol yielded characteristic ion at $m / z 285$, indicating the combination loss of a glucose, a pentose and a glucuronic acid moiety $(470 \mathrm{Da})[58,63]$.

\section{Isoflavonoid Derivatives}

A total of 10 isoflavonoid compounds were tentatively identified in custard apples. Sativanone with $[\mathrm{M}-\mathrm{H}]^{-}$ion at $m / z 299.0914$ was exclusively detected in African Pride peel, exhibiting the fragment ions at $m / z 284, m / z 269$ and $m / z 225$ because of the cleavage of $\mathrm{CH}_{3}(15 \mathrm{Da})$ from the $\mathrm{B}$ ring, the loss of two $\mathrm{CH}_{3}(30 \mathrm{Da})$ and the loss of two $\mathrm{CH}_{3}$ plus $\mathrm{CO}_{2}(74 \mathrm{Da})$, respectively [64]. Compound 56 found in Pink's Mammoth pulp with [M $\mathrm{H}]^{-}$ion at $m / z 329.1030$ was suggested to be 3'-O-methylviolanone. The $\mathrm{MS}^{2}$ spectrum of the compound gave product ions in negative mode at $m / z 314$ [M-H-CH$\left.-\mathrm{H}_{3}\right], m / z 299$ [M $\mathrm{H}-2 \mathrm{CH}_{3} \cdot, m / z 284\left[\mathrm{M}-\mathrm{H}-3 \mathrm{CH}_{3}-\right.$ and $m / z 256\left[\mathrm{M}-\mathrm{H}-3 \mathrm{CH}_{3}-\mathrm{CO}\right.$ ] [65]. Compounds 60, 61 and 62 at positive ionization mode $\left(\mathrm{ESI}^{+}\right)$were assigned as genistein, glycitin and daidzin derivatives and were exclusively detected in APE, PPE and PSE, respectively. In the study of George et al. [1], genistein and glycitein were identified in the aqueous extract of A. muricata and daidzein was detected in methanolic extract of $A$. muricata by HPLC.

\subsubsection{Lignans and Stilbenes}

Lignans and stilbenes are essential classes of polyphenols correlated with plant defense [66]. In total, six lignans and four stilbenes were tentatively characterized in the current research.

\section{Lignan Derivatives}

Compound $64\left([\mathrm{M}-\mathrm{H}]^{-}\right.$at $m / z$ 357.1343) was matairesinol and was detected in Pink's Mammoth pulp. The characterization was confirmed by the product ions at $m / z$ $342, m / z 327, m / z 313$ and $m / z 221$, corresponding to the loss of $\mathrm{CH}_{3}, \mathrm{C}_{2} \mathrm{H}_{6}, \mathrm{CO}_{2}$ and $\mathrm{C}_{8} \mathrm{H}_{8} \mathrm{O}_{2}$, respectively. Previously, this compound was characterized in Acanthopanax senticosus stem [67]. Compound 65 was proposed to be enterolactone identified in Pink's Mammoth seed and peel and had major fragment ions at $m / z 281$ and $m / z 165$ because of the loss of water and $\mathrm{C}_{9} \mathrm{H}_{10} \mathrm{O}$ [68]. Secoisolariciresinol-sesquilignan precursor ion at [M $\mathrm{H}^{-}$at $m / z 557.2391$ was designated as compound 68, with product ions at $m / z 539, \mathrm{~m} / z$ $521, m / z 509$ and $m / z 361$ due to the loss of a single water molecule, two water molecules, $\mathrm{HOCH}_{2} \mathrm{OH}$ and guaiacylglycerol, respectively [69]. In addition, two other lignans named schisanhenol (Compound 66) and schisandrin (Compound 67) were also tentatively characterized in soursop peel and Pink's Mammoth seed, respectively. The former lignan presented multiple ions at $m / z 385, m / z 354$ and $m / z 331$, whereas the latter compound had fragment ions at $m / z 415, m / z 384$ and $m / z 361$ due to the loss of $\mathrm{H}_{2} \mathrm{O}, \mathrm{H}_{2} \mathrm{O}-\mathrm{OCH}_{3}$ and $\mathrm{H}_{2} \mathrm{O}-\mathrm{C}_{4} \mathrm{H}_{6}$ [70]. Dutra et al. [71] previously isolated three lignans (eudesmin, magnolin and yangambin) from leaves of Annona pickelii. 


\section{Stilbene Derivatives}

To the best of our knowledge, this was the first time that the stilbenes were reported in custard apple. Compound 69 present in negative mode at $\mathrm{m} / z 405.1172$ was confirmed to be piceatannol 3-O-glucoside by fragment ion at $m / z 243$ [M-H-glucoside] [72]. Resveratrol (Compound 71) was confirmed by the $\mathrm{MS}^{2}$ spectrum and comparison with the previous literature. The $\mathrm{MS}^{2}$ spectrum presented fragment ion at $m / z 185$, corresponding to the loss of $\mathrm{CHCOH}$ group, while the other two ions at $m / z 157$ and $m / z 143$ were due to the loss of $\mathrm{CO}$ and $\mathrm{C}_{2} \mathrm{H}_{2} \mathrm{O}$ [73]. According to the literature, stilbenes serve various bioactive functions such as cardioprotection, tumor resistance and bacterial and fungal resistance [74].

\subsubsection{Other Polyphenols}

The other polyphenols identified in custard apple (a total of 13) can be classified into curcuminoids (1), furanocoumarins (1), hydroxybenzaldehydes (2), hydroxy-benzoketones (3), hydroxyphenylpropenes (1), phenolic terpenes (2) and tyrosols (3).

Compound 79 with $[\mathrm{M}+\mathrm{H}]^{+}$ion at $m / z 147.0442$ was tentatively characterized as coumarin. According to the $\mathrm{MS}^{2}$ spectrum, the $[\mathrm{M}+\mathrm{H}]^{+}$ion gave characteristic ions at $\mathrm{m} / \mathrm{z}$ 103 and $m / z 91$ due to the elimination of $\mathrm{CO}_{2}$ and $\cdot \mathrm{HC}-\mathrm{CO}_{2}$, respectively [75]. The presence of coumarin in the bark of Annona senegalensis was previously reported in the research by Inkoto et al. [76], while Anaya Esparza and Montalvo-González [59] likewise characterized this compound in the extract of soursop. Sonkar et al. [77] reported the exhibition of liver protective function in rats from the coumarins present in the extract of Annona squamosa.

Rosmanol (compound 81 with $[\mathrm{M}+\mathrm{H}]^{+}$at $m / z$ 347.1844) was identified in Pink's Mammoth pulp and soursop peel. The MS/MS spectrum characterized the compound at $m / z$ 301, indicating loss of a water molecule and CO (46 Da) [78]. The presence of phenolic terpenoids in the seed of sugar apple (Annona squamosa L.) had already been reported by Huang et al. [50]. Hydroxytyrosol 4-O-glucoside (compound 83) was identified in both positive $\left(\mathrm{ESI}^{+}\right)$and negative $\left(\mathrm{ESI}^{-}\right)$ionization modes yielding the product ions at $m / z 153$ and $m / z 123$, corresponding to loss of hexose and a $\mathrm{CH}_{2} \mathrm{O}$ group. Previously, Khallouki et al. [79] identified tyrosols in methanolic extract of root and bark of Annona cuneate.

Overall, the screening and characterization of phenolic compounds via LC-ESI-QTOFMS/MS created a profile for the phenolics of custard apple that enables easier estimation and analysis of the antioxidant properties. The outcome displays that custard apple possesses abundant phenolic compounds and indicates that custard apple has a high potential to be used as polyphenol resources in food and pharmaceutical domains.

\subsection{Distribution of Phenolic Compounds-Venn Diagram}

In the current study, Venn diagrams were plotted to provide additional information on the distribution of phenolic compounds in African Pride, Pink's Mammoth and soursop custard apples. The comparison clearly reveals that the phenolic constituents in different custard apples are diverse, which results in differences in antioxidant potential among the varieties.

Figure 1A shows that a total of 338 compounds were tentatively identified in all nine custard apple samples. Of the total phenolic compounds, $17.5 \%$ were possessed by all three custard apples. The percentage for shared phenolic acids in three custard apple fruits was very similar to that of the total phenolics (19\%). Unlike phenolic acids, flavonoids have a relatively lower proportion of commonly shared compounds $(9.1 \%)$, whereas a much higher percentage $(27 \%)$ was noted for the other phenolic compounds. Based on such low shared proportions, it was apparent that there was a great variation for phenolic constituents in different varieties of custard apples. As shown in Figure 1C, $42.9 \%$ of the flavonoid compounds were shared in African Pride and Pink's Mammoth. This result can be explained by both African Pride and Pink's Mammoth belonging to Annona atemoya, and the large overlapped zone might be produced due to the shared compounds of this 
specific Annona species. In the soursop variety, the unique compounds were low when compared to other varieties.

(A)

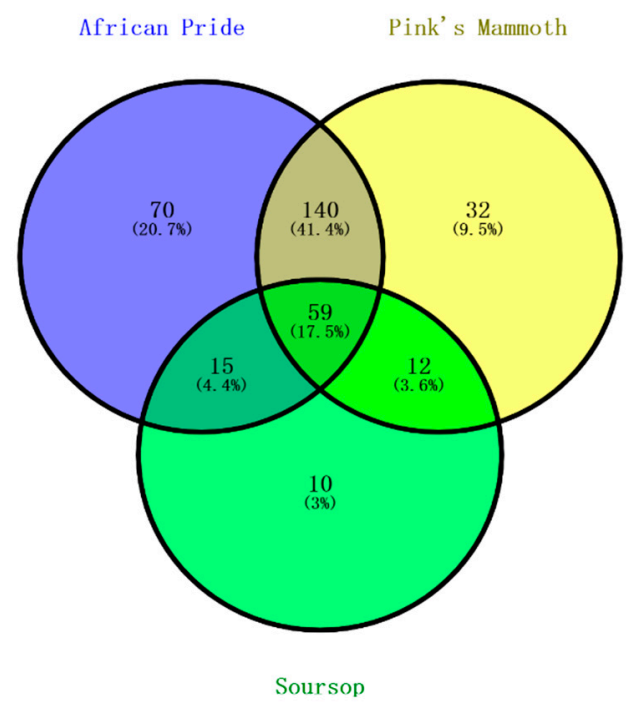

(C)

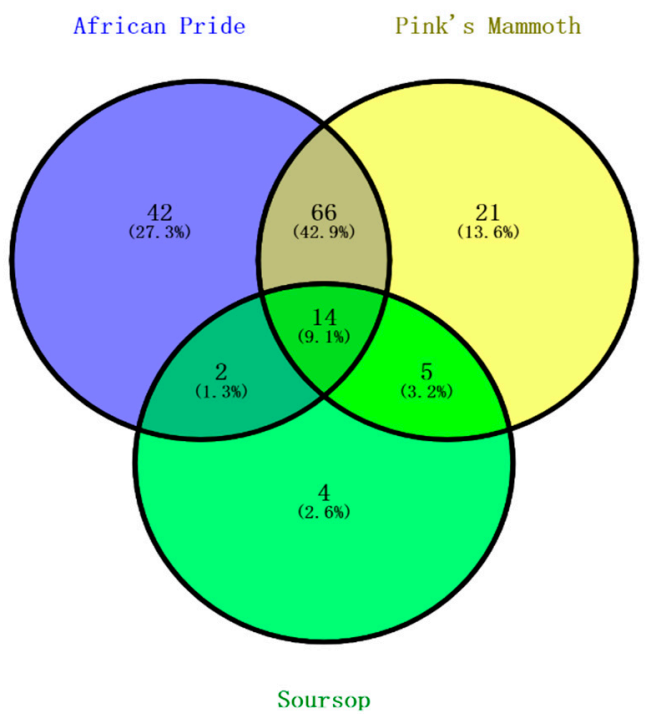

(B)

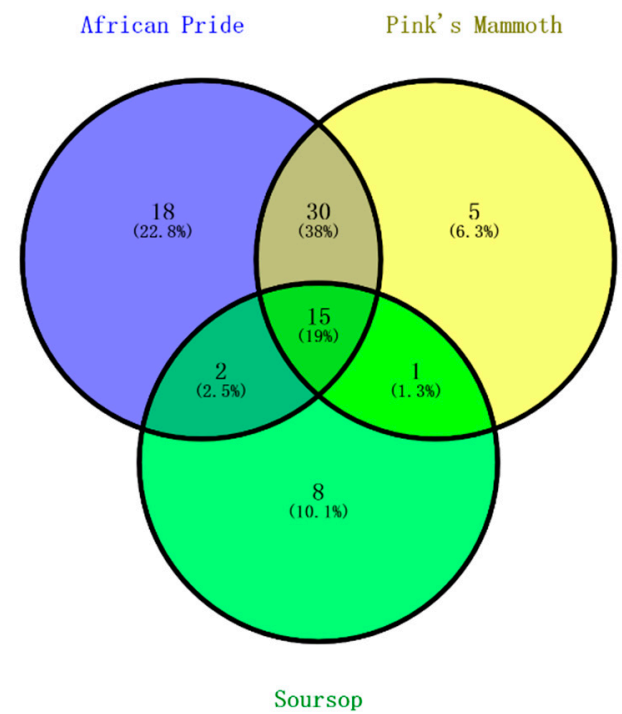

(D)

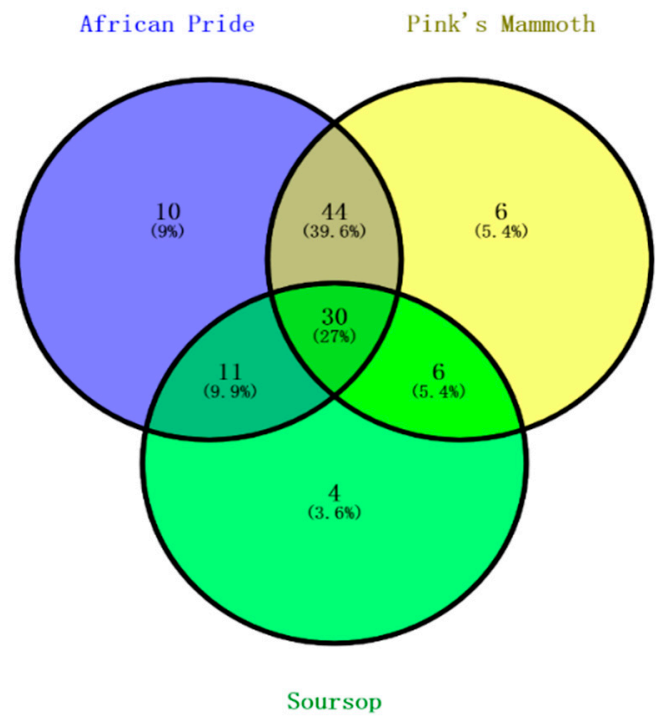

Figure 1. Venn diagram of the distribution of phenolic compounds in various custard apple varieties. The relations of (A) total phenolic compounds, (B) phenolic acids, (C) total flavonoids and (D) other phenolic compounds in three custard apples.

As shown Figure 2A, 38.5\% of phenolic compounds were shared among the peel, pulp and seed, and $19.5 \%$ of compounds were shared between peels and seeds. Considering unique compounds, $17.2 \%$ were found in peel, $8.6 \%$ in seeds and $3.6 \%$ in pulps. The peels have higher levels of phenolic compounds due to the exposure to the outer environment, and this result was previously found in the peel of custard apple [29]. As shown in Figure 2B,C, the highest number of unique compounds was found in African Pride peel and seed, followed by Pink's Mammoth and soursop. Figure 2D shows that the Pink's Mammoth pulp had more unique compounds than African Pride and soursop. The proportions of overlap of the varieties in seed and pulp were $3.8 \%$ and $2.7 \%$, respectively. Previously, a study reported that the total phenolic contents were low in soursop, which is similar to our study [6]. 
(A)

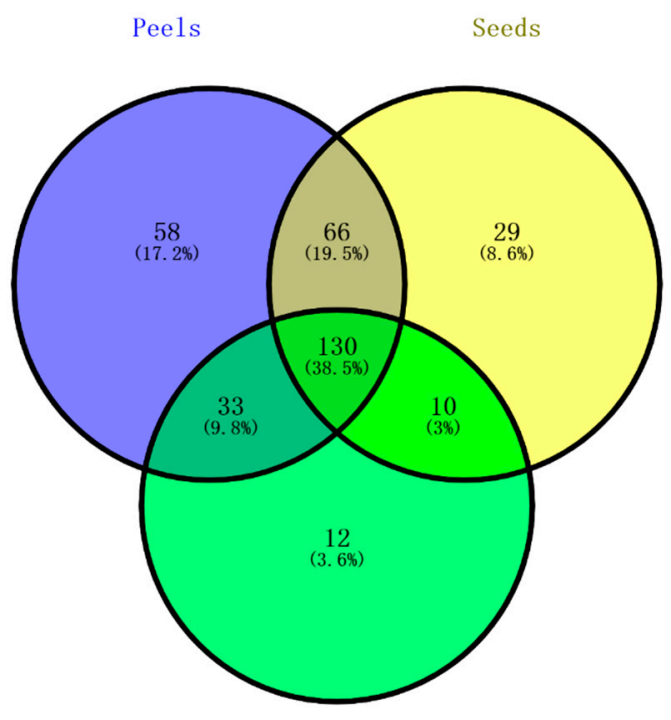

Pulps

(C)

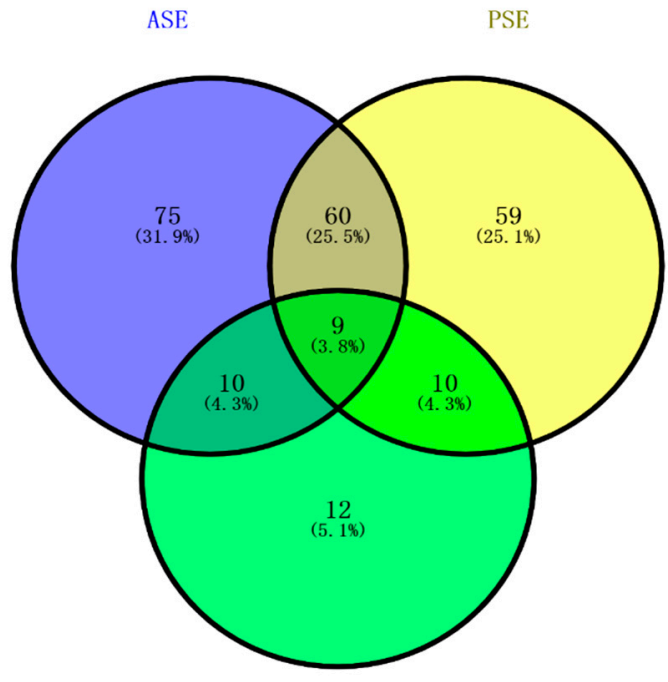

SSE
(B)

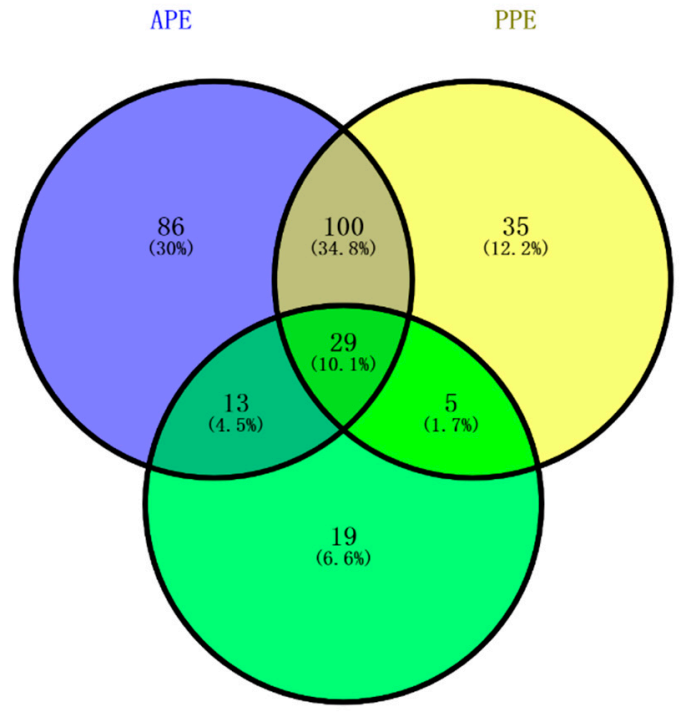

SPE

(D)

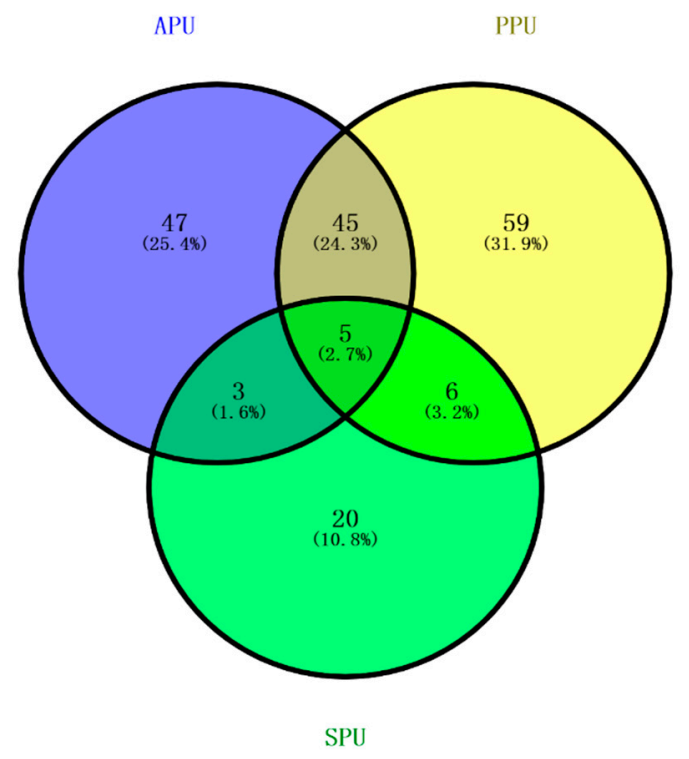

Figure 2. Venn diagram of the distribution of phenolic compounds in various custard apple portions, including peel, seeds and pulp. The relations of (A) total phenolic compounds present in three portions of custard apple, (B) phenolic compounds in peels, (C) phenolic compounds in seeds and (D) phenolic compounds in pulps.

The findings in this section further verified the variation of phenolic compounds in different custard apples, and we found that the flavonoids were primarily responsible for the differences. Moreover, the peel sections seem to have numerous compounds among the various portions of custard apples, whereas soursop had the fewest phenolic compounds. Further analysis might be required to investigate the impact of individual phenolic compounds on antioxidant capacity.

\subsection{Heat Map and Hierarchical Clustering Analysis of Phenolic Compounds}

In the heatmap (Figure 3), there are two clusters in rows and four clusters in columns presented in the form of hierarchical clustering, and each cluster was generated by different samples representing a unique cluster with significant differentials in their phenolic profiles. The color of samples displays whether the contents of the targeted phenolics (phenolic 
acids and flavonoids) present in the custard apple samples were relatively abundant. According to the result, PPE, APE, PPU, APU and SSE were grouped into a cluster since they possess a high level of similar phenolic contents. It is worth noting that within this cluster, the contents of quercetin-3-rhamnoside, $p$-hydroxybenzoic acid, syringic acid and quercetin-3-glucoside were high in APE (marked with deep purple color). Apart from the horizontal clustering, phenolic compounds could also be vertically classified into four major clusters (PC-1, PC-2, PC-3 and PC-4) and several sub-clusters that were then distributed based on the concentration similarity in the custard apple samples. The map showed that both quercetin and protocatechuic acid were diverse in terms of the concentration among the samples, while the other phenolic acids and flavonoids tended to have higher similarity.

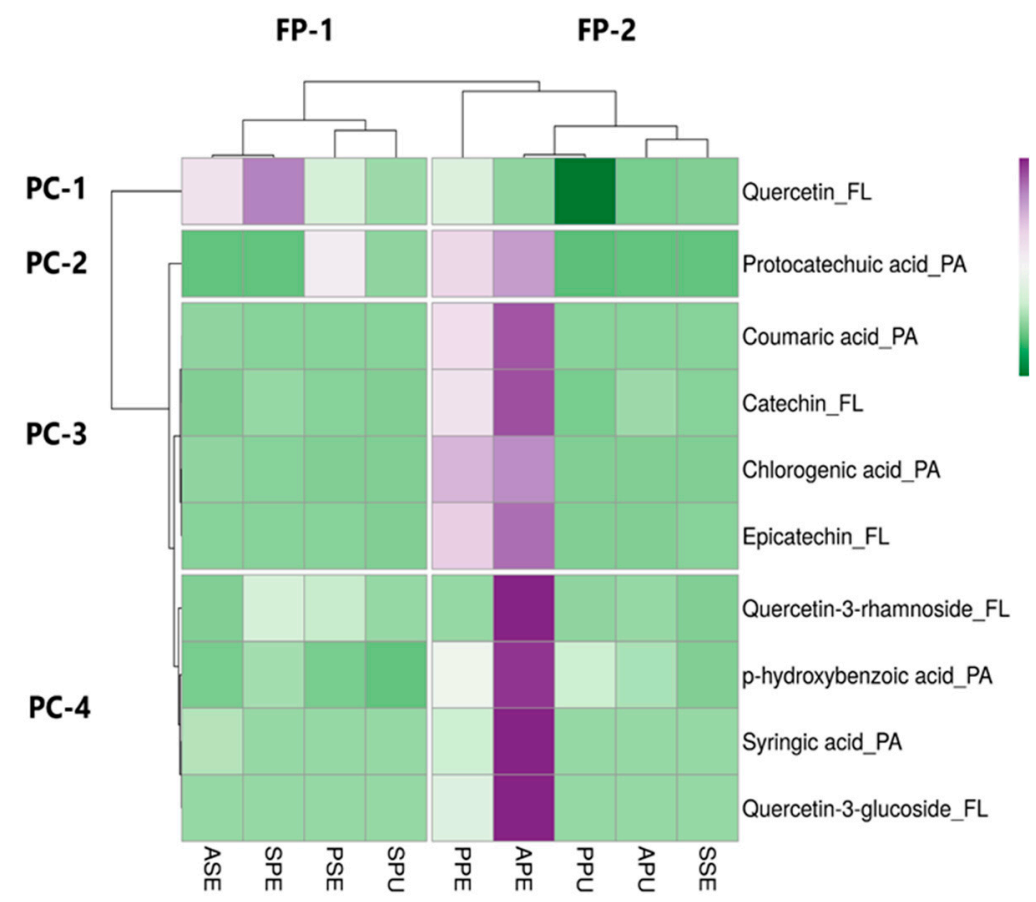

Figure 3. Heatmap displaying the distribution of phenolic compounds and the concentration among custard apple samples. Purple boxes represent the compounds with higher concentrations; green boxes represent the compounds with lower concentrations. African Pride peel, seed and pulp are abbreviated as APE, ASE and APU, respectively; Pink's Mammoth peel, seed and pulp are abbreviated as PPE, ASE and PPU, respectively; soursop peel, seed and pulp are abbreviated as SPE, SSE and SPU, respectively; phenolic acids and flavonoids are abbreviated as PA and FL, respectively; phenolic compound clusters and fruit phenolic clusters are abbreviated as PC and FP, respectively.

Protocatechuic acid was quantified from the peel of African pride variety in our study, and the concentration was relatively high. Protocatechuic acid was also previously reported in the annonaceous fruit called araticum (Annona crassiflora Mart.), and the concentration was higher than that found in the African Pride cultivar [80]. The concentration of chlorogenic acid in African Pride peel and Pink's Mammoth peel was comparatively higher than that in African Pride seed and soursop peel. It is worth noting that chlorogenic acid was characterized and quantified in the peel section of all examined fruits, which suggests that perhaps this phenolic compound is abundant in Annona fruits. A recent study that measured the chlorogenic acid in the pulp of some edible Annonaceae fruits, including atemoya and soursop, reported a very low concentration of chlorogenic acid, and the compound was not detected in soursop pulp [27]. $p$-Coumaric acid was found in high concentration in the peel of African Pride and Pink's Mammoth. Arruda et al. [80] previously reported a low concentration of $p$-coumaric acid in the peel of araticum fruits. In addition, a negligible amount of $p$-hydroxybenzoic acid was detected in the peel of 
Pink's Mammoth, while the compound syringic acid was reported for the first time in custard apple to the best of our knowledge.

With regards to flavonoid, the concentration was low when compared to phenolic acid. Catechin and epicatechin were quantified in Pink's Mammoth seed and African Pride seed. Previously, de Moraes et al. [9] had quantified catechin in atemoya pulp and the reported concentration was $38.6 \pm 0.72 \mu \mathrm{g} / \mathrm{g}_{\text {d.w. }}$, whereas epicatechin was comparatively abundant, showing the concentration of $211 \pm 2.2 \mu \mathrm{g} / \mathrm{g}_{\text {d.w. }}$ in the same sample. Three quercetin derivatives were detected in Pink's Mammoth peel. The concentrations of quercetin-3galactoside $(\mathrm{RT}=39.624 \mathrm{~min})$ and quercetin-3-glucoside $(\mathrm{RT}=40.485 \mathrm{~min})$ were similar, while a much lower concentration was reported for quercetin-3-rhamnoside. Alvionita and Oktavia [81] reported the presence of quercetin-3-glucoside in the leaf extracts of Annona squamosa L. and indicated that this compound has the properties of an antigout drug due to the strong inhibitory effect on xanthine oxidase. Quercetin was present in both peel and seed portions of Pink's Mammoth. The concentration of quercetin for the araticum peel was similar to our research [80]. The findings in de Moraes et al. [9] showed consistency with our research since no detection was reported in the pulp portion of atemoya and soursop.

\subsection{Correlation between Antioxidant Assays and Phenolic Content}

Pearson's correlation coefficients showed phenolic content and antioxidant activity were closely correlated, and all antioxidant capabilities were correlative except the DPPH radical scavenging activity (Table 3 ).

Table 3. Linear correlation coefficients $\left(r^{2}\right)$ for the relationships between phenolics and antioxidant assays.

\begin{tabular}{|c|c|c|c|c|c|c|c|c|c|c|c|}
\hline Variables & TPC & TFC & TTC & DPPH & FRAP & ABTS & RPA & $\begin{array}{l}\bullet \mathrm{OH}- \\
\text { RSA }\end{array}$ & FICA & TAC & Phenolic Acids \\
\hline TFC & $0.702 *$ & & & & & & & & & & \\
\hline TTC & $0.997 * *$ & $0.690 *$ & & & & & & & & & \\
\hline DPPH & 0.036 & 0.204 & -0.002 & & & & & & & & \\
\hline FRAP & $0.974 * *$ & 0.627 & $0.986^{* *}$ & -0.116 & & & & & & & \\
\hline ABTS & $0.998 * *$ & $0.706 *$ & $1.000^{* *}$ & 0.019 & 0.983 ** & & & & & & \\
\hline RPA & 0.262 & $0.709 *$ & 0.249 & 0.341 & 0.213 & 0.269 & & & & & \\
\hline $\begin{array}{l}{ }^{\bullet O H}- \\
\text { RSA }\end{array}$ & 0.295 & -0.233 & 0.269 & 0.444 & 0.209 & 0.266 & -0.492 & & & & \\
\hline FICA & 0.034 & 0.110 & 0.005 & 0.119 & -0.059 & 0.015 & 0.228 & 0.025 & & & \\
\hline TAC & $0.993^{* *}$ & $0.685^{*}$ & 0.998 ** & -0.027 & $0.989 * *$ & $0.997^{* *}$ & 0.264 & 0.235 & 0.017 & & \\
\hline $\begin{array}{l}\text { Phenolic } \\
\text { acids }\end{array}$ & $0.994^{* *}$ & 0.689 * & $0.990 * *$ & 0.076 & $0.960 * *$ & 0.991 ** & 0.281 & 0.316 & 0.115 & $0.988^{* *}$ & \\
\hline Flavonoids & $0.954^{* *}$ & $0.682 *$ & $0.933 * *$ & 0.213 & $0.874^{* *}$ & $0.939 * *$ & 0.305 & 0.401 & 0.265 & $0.927^{* *}$ & $0.973 * *$ \\
\hline
\end{tabular}

** Significant correlation with $p<0.01 .{ }^{*}$ Significant correlation with $p<0.05$.

In brief, TPC had highly significant positive correlations with ferric reducing ability of plasma, total antioxidant capacity and ABTS radical scavenging activity with $r^{2}$ values of $0.974(p<0.01), 0.993(p<0.01)$ and $0.998(p<0.01)$, respectively. TFC also displayed significant positive correlations with total antioxidant capacity and ABTS radical scavenging activity with $r^{2}$ values of $0.685(p<0.05)$ and $0.706(p<0.05)$, respectively. RPA and TFC showed positive correlation with $r^{2}$ value of $0.709(p<0.05)$. Similarly, TTC exhibited a highly significant correlation with most of the antioxidant activities assessed in our study, such as ferric reducing ability of plasma $\left(r^{2}=0.986\right)$ and total antioxidant capacity $\left(r^{2}=0.998\right)$, but lacked correlation with DPPH radical scavenging activity. Correlations between ABTS radical scavenging activity and total antioxidant capacity were found to be highly interrelated in our research. Manochai et al. [5] reported a strong correlation between TPC and ABTS radical scavenging activity and ferric reducing ability of plasma with $r^{2}$ values of $0.958(p<0.01)$ and $0.995(p<0.01)$, respectively, when analyzing the peel of 10 sugar apples. Nam et al. [43] obtained a negative correlation between DPPH radical scavenging activity, TPC and other antioxidant activities in pawpaw, and their results were similar to our study.

Phenolic acids and flavonoids quantified by HPLC had a significant correlation with the antioxidant activities except for the DPPH, which was similar to the previous correlation in our study. Phenolic acids detected by HPLC had highly significant positive 
correlations with ferric reducing ability, total antioxidant capacity and ABTS radical scavenging activity with $r^{2}$ values of $0.960,0.988$ and 0.991 at the significance level of 0.01 . Similarly, the flavonoids detected by HPLC-PDA were found to be closely correlated with ferric reducing ability $\left(r^{2}=0.874\right)$, total antioxidant capacity $\left(r^{2}=0.927\right)$ and ABTS radical scavenging activity $\left(r^{2}=0.939\right)$. Therefore, it can be concluded that both phenolic acids and flavonoids in custard apple are highly correlated to antioxidant potential.

\section{Conclusions}

This study is the first to provide the comprehensive phenolic profiles of Australian grown custard apples, and it also examined the phenolic content and antioxidant potential in different sections of custard apples. In conclusion, Australian grown custard apples exhibit promising phenolic contents and antioxidant capacity. According to the results, different portions of the custard apple have high concentrations of phenolic compounds that are closely correlated with strong antioxidant capacity. The application of LC-ESI-QTOF-MS/MS technique successfully separated and characterized a total of 85 phenolic compounds in the custard apples, while the HPLC-PDA quantified the most abundant phenolic compounds. The outcome of this study shows that each part of the custard apple could be a good source of phenolic compounds. The peel and seed of custard apple have high phenolic content and strong antioxidant activity; due to their potential value, these portions can be used in the field of food and nutraceutical industries. Future studies, including toxicological and animal studies, may support further application and boost development in relevant industries.

Supplementary Materials: The following are available online at https:/ /www.mdpi.com/article/10 .3390/separations8050062/s1, Figure S1: LC-ESI-QTOF-MS/MS basic peak chromatograph (BPC) for characterization of phenolic compounds of custard apple peel. Figure S2: LC-ESI-QTOF-MS/MS basic peak chromatograph (BPC) for characterization of phenolic compounds of custard apple seeds. Figure S3: LC-ESI-QTOF-MS/MS basic peak chromatograph (BPC) for characterization of phenolic compounds of custard apple pulp.

Author Contributions: Conceptualization, methodology, formal analysis, validation and investigation, J.D., B.Z., V.S. and H.A.R.S.; resources, H.A.R.S., C.J.B. and F.R.D.; writing-original draft preparation, J.D. and B.Z.; writing-review and editing, V.S., B.Z., C.J.B., H.A.R.S. and F.R.D.; supervision, H.A.R.S. and F.R.D.; idea sharing, H.A.R.S., C.J.B. and F.R.D.; funding acquisition, H.A.R.S., F.R.D. and C.J.B. All authors have read and agreed to the published version of the manuscript.

Funding: This research was funded by the University of Melbourne under the "McKenzie Fellowship Scheme" (Grant No. UoM-18/21), the "Richard WS Nicholas Agricultural Science Scholarship" and the "Faculty Research Initiative Funds" funded by the Faculty of Veterinary and Agricultural Sciences, The University of Melbourne, Australia and "The Alfred Deakin Research Fellowship" funded by Deakin University, Australia.

Institutional Review Board Statement: Not applicable.

Informed Consent Statement: Not applicable.

Data Availability Statement: The data presented in this study are available in the supplementary materials.

Acknowledgments: We would like to thank Nicholas Williamson, Shuai Nie and Michael Leeming from the Mass Spectrometry and Proteomics Facility, Bio21 Molecular Science and Biotechnology Institute, the University of Melbourne, VIC, Australia for providing access and support for the use of HPLC-PDA and LC-ESI-QTOF-MS/MS and data analysis.

Conflicts of Interest: The authors declare no conflict of interest. 


\section{References}

1. George, V.C.; Kumar, D.R.; Suresh, P.K.; Kumar, R.A. Antioxidant, DNA protective efficacy and hplc analysis of Annona muricata (soursop) extracts. J. Food Sci. Technol. 2015, 52, 2328-2335. [CrossRef]

2. Encina, C.L. 3.1 Annona spp. Atemoya, cherimoya, soursop and sugar apple. In Biotechnology of Fruit and Nut Crops; The Doyle Foundation: Glasgow, Scotland, 2005; p. 74.

3. Orsi, D.C.; Carvalho, V.S.; Nishi, A.C.F.; Damiani, C.; Asquieri, E.R. Use of sugar apple, atemoya and soursop for technological development of jams: Chemical and sensorial composition. Ciência e Agrotecnologia 2012, 36, 560-566. [CrossRef]

4. Adefegha, S.A.; Oyeleye, S.I.; Oboh, G. Distribution of phenolic contents, antidiabetic potentials, antihypertensive properties, and antioxidative effects of soursop (Annona muricata L.) fruit parts in vitro. Biochem. Res. Int. 2015, 2015, 347673. [CrossRef]

5. Manochai, B.; Ingkasupart, P.; Lee, S.H.; Hong, J.H. Evaluation of antioxidant activities, total phenolic content (TPC), and total catechin content (TCC) of 10 sugar apple (Annona squamosa L.) cultivar peels grown in thailand. Food Sci. Technol. 2018, 38, 294-300. [CrossRef]

6. Ellong, E.N.; Billard, C.; Adenet, S.; Rochefort, K. Polyphenols, carotenoids, vitamin c content in tropical fruits and vegetables and impact of processing methods. Food Nutr. Sci. 2015, 6, 299. [CrossRef]

7. Ferrazzano, G.F.; Amato, I.; Ingenito, A.; Zarrelli, A.; Pinto, G.; Pollio, A. Plant polyphenols and their anti-cariogenic properties: A review. Molecules 2011, 16, 1486-1507. [CrossRef] [PubMed]

8. Subbiah, V.; Zhong, B.; Nawaz, M.A.; Barrow, C.J.; Dunshea, F.R.; Suleria, H.A. Screening of phenolic compounds in australian grown berries by lc-esi-qtof-ms/ms and determination of their antioxidant potential. Antioxidants 2021, 10, 26. [CrossRef]

9. De Moraes, M.R.; Ryan, S.M.; Godoy, H.T.; Thomas, A.L.; Maia, J.G.S.; Richards, K.M.; Tran, K.; Smith, R.E. Phenolic compounds and metals in some edible annonaceae fruits. Biol. Trace Elem. Res. 2020, 197, 676-682. [CrossRef]

10. Ali, A.; Wu, H.; Ponnampalam, E.N.; Cottrell, J.J.; Dunshea, F.R.; Suleria, H.A.R. Comprehensive profiling of most widely used spices for their phenolic compounds through lc-esi-qtof-ms2 and their antioxidant potential. Antioxidants 2021, 10, 721. [CrossRef]

11. Feng, Y.; Dunshea, F.R.; Suleria, H.A.R. LC-ESI-QTOF/MS characterization of bioactive compounds from black spices and their potential antioxidant activities. J. Food Sci. Technol. 2020, 57, 4671-4687. [CrossRef]

12. Peng, D.; Zahid, H.F.; Ajlouni, S.; Dunshea, F.R.; Suleria, H.A.R. Lc-esi-qtof/ms profiling of australian mango peel by-product polyphenols and their potential antioxidant activities. Processes 2019, 7, 764. [CrossRef]

13. Chen, Z.; Zhong, B.; Barrow, C.J.; Dunshea, F.R.; Suleria, H.A.R. Identification of phenolic compounds in australian grown dragon fruits by lc-esi-qtof-ms/ms and determination of their antioxidant potential. Arab. J. Chem. 2021, 14, 103151. [CrossRef]

14. Gu, C.; Howell, K.; Dunshea, F.R.; Suleria, H.A. LC-ESI-QTOF/MS characterisation of phenolic acids and flavonoids in polyphenolrich fruits and vegetables and their potential antioxidant activities. Antioxidants 2019, 8, 405. [CrossRef]

15. Zhu, C.; Chou, O.; Lee, F.Y.; Wang, Z.; Barrow, C.J.; Dunshea, F.R.; Suleria, H.A.R. Characterization of phenolics in rejected kiwifruit and their antioxidant potential. Processes 2021, 9, 781. [CrossRef]

16. Suleria, H.A.R.; Barrow, C.J.; Dunshea, F.R. Screening and characterization of phenolic compounds and their antioxidant capacity in different fruit peels. Foods 2020, 9, 1206. [CrossRef] [PubMed]

17. Samsonowicz, M.; Regulska, E.; Karpowicz, D.; Leśniewska, B. Antioxidant properties of coffee substitutes rich in polyphenols and minerals. Food Chem. 2019, 278, 101-109. [CrossRef]

18. Stavrou, I.J.; Christou, A.; Kapnissi-Christodoulou, C.P. Polyphenols in carobs: A review on their composition, antioxidant capacity and cytotoxic effects, and health impact. Food Chem. 2018, 269, 355-374. [CrossRef]

19. Haile, M.; Kang, W.H. Antioxidant activity, total polyphenol, flavonoid and tannin contents of fermented green coffee beans with selected yeasts. Fermentation 2019, 5, 29. [CrossRef]

20. Sogi, D.S.; Siddiq, M.; Greiby, I.; Dolan, K.D. Total phenolics, antioxidant activity, and functional properties of 'tommy atkins' mango peel and kernel as affected by drying methods. Food Chem. 2013, 141, 2649-2655. [CrossRef]

21. Ferreira, I.C.; Baptista, P.; Vilas-Boas, M.; Barros, L. Free-radical scavenging capacity and reducing power of wild edible mushrooms from northeast portugal: Individual cap and stipe activity. Food Chem. 2007, 100, 1511-1516. [CrossRef]

22. Smirnoff, N.; Cumbes, Q.J. Hydroxyl radical scavenging activity of compatible solutes. Phytochemistry 1989, 28, 1057-1060. [CrossRef]

23. Dinis, T.C.; Madeira, V.M.; Almeida, L.M. Action of phenolic derivatives (acetaminophen, salicylate, and 5-aminosalicylate) as inhibitors of membrane lipid peroxidation and as peroxyl radical scavengers. Arch. Biochem. Biophys. 1994, 315, 161-169. [CrossRef] [PubMed]

24. Serquiz, A.; Alves, M.; Fernandes-Negreiros, M.; Rocha, H. In vitro antioxidant activity of aqueous extracts from the atemoya fruit (peel, pulp, and seed): Correlation of their protein, carbohydrate, and phenolic compound contents. J. Adv. Food Technol. 2018, 1, 103.

25. Zhong, B.; Robinson, N.A.; Warner, R.D.; Barrow, C.J.; Dunshea, F.R.; Suleria, H.A. LC-ESI-QTOF-MS/MS characterization of seaweed phenolics and their antioxidant potential. Mar. Drugs 2020, 18, 331. [CrossRef] [PubMed]

26. Ma, C.; Dunshea, F.R.; Suleria, H.A.R. LC-ESI-QTOF/MS characterization of phenolic compounds in palm fruits (jelly and fishtail palm) and their potential antioxidant activities. Antioxidants 2019, 8, 483. [CrossRef]

27. Santos, W.N.D.; Sauthier, M.C.S.; Cavalcante, D.D.; Benevides, C.M.; Dias, F.S.; Santos, D. Mineral composition, nutritional properties, total phenolics and flavonoids compounds of the atemoya fruit (Annona squamosa L. $\times$ Annona cherimola mill.) and evaluation using multivariate analysis techniques. An. Acad. Bras. Ciênc. 2016, 88, 1243-1252. [CrossRef] 
28. Zamudio-Cuevas, Y.; Díaz-Sobac, R.; Vázquez-Luna, A.; Landa-Solís, C.; Cruz-Ramos, M.; Santamaría-Olmedo, M.; MartínezFlores, K.; Fuentes-Gómez, A.; López-Reyes, A. The antioxidant activity of soursop decreases the expression of a member of the nadph oxidase family. Food Funct. 2014, 5, 303-309. [CrossRef] [PubMed]

29. Sasidharan, S.; Jayadev, A. A comparative analysis of anti oxidant properties of three varieties of Annona sp. Int. J. Appl. Res. 2017, 3, 1174-1178.

30. Lydia, D.E.; John, S.; Swetha, V.; Sivapriya, T. Investigation on the antimicrobial and antioxidant activity of custard apple (Annona reticulata) peel extracts. Res. J. Pharmacogn. Phytochem. 2017, 9, 241-247. [CrossRef]

31. Wojdylo, A.; Oszmianski, J.; Laskowski, P. Polyphenolic compounds and antioxidant activity of new and old apple varieties. J. Agric. Food Chem. 2008, 56, 6520-6530. [CrossRef]

32. Akomolafe, S.; Ajayi, O.B. A comparative study on antioxidant properties, proximate and mineral compositions of the peel and pulp of ripe Annona muricata (L.) fruit. Int. Food Res. J. 2015, 22, 2381-2388.

33. Yang, D.; Dunshea, F.R.; Suleria, H.A. Lc-esi-qtof/ms characterization of australian herb and spices (garlic, ginger, and onion) and potential antioxidant activity. J. Food Process. Preserv. 2020, 44, e14497. [CrossRef]

34. Boakye, A.A. Assessment of Some Health Beneficial Constituents of Edible Portions of Four Underutilised Fruits. Master's Thesis, University of Ghana, Accra, Ghana, 2013.

35. Murillo, E.; Britton, G.B.; Durant, A.A. Antioxidant activity and polyphenol content in cultivated and wild edible fruits grown in panama. J. Pharm. Bioallied Sci. 2012, 4, 313-317.

36. Agu, K.C.; Okolie, P.N. Proximate composition, phytochemical analysis, and in vitro antioxidant potentials of extracts of Annona muricata (soursop). Food Sci. Nutr. 2017, 5, 1029-1036. [CrossRef]

37. Al-Nemari, R.; Al-Senaidy, A.; Semlali, A.; Ismael, M.; Badjah-Hadj-Ahmed, A.Y.; Bacha, A.B. Gc-ms profiling and assessment of antioxidant, antibacterial, and anticancer properties of extracts of Annona squamosa L. Leaves. BMC Complement. Med. Ther. 2020, 20, 296. [CrossRef] [PubMed]

38. Nandhakumar, E.; Indumathi, P. In vitro antioxidant activities of methanol and aqueous extract of Annona squamosa (L.) fruit pulp. J. Acupunct. Meridian Stud. 2013, 6, 142-148. [CrossRef] [PubMed]

39. Escobar-Avello, D.; Lozano-Castellón, J.; Mardones, C.; Pérez, A.J.; Saéz, V.; Riquelme, S.; von Baer, D.; Vallverdú-Queralt, A. Phenolic profile of grape canes: Novel compounds identified by lc-esi-ltq-orbitrap-ms. Molecules 2019, $24,3763$.

40. Hossain, M.B.; Rai, D.K.; Brunton, N.P.; Martin-Diana, A.B.; Barry-Ryan, C. Characterization of phenolic composition in lamiaceae spices by LC-ESI-MS/MS. J. Agric. Food Chem. 2010, 58, 10576-10581. [CrossRef]

41. Sasot, G.; Martínez-Huélamo, M.; Vallverdú-Queralt, A.; Mercader-Martí, M.; Estruch, R.; Lamuela-Raventós, R.M. Identification of phenolic metabolites in human urine after the intake of a functional food made from grape extract by a high resolution ltq-orbitrap-ms approach. Food Res. Int. 2017, 100, 435-444. [CrossRef]

42. Roesler, R.; Catharino, R.R.; Malta, L.G.; Eberlin, M.N.; Pastore, G. Antioxidant activity of annona crassiflora: Characterization of major components by electrospray ionization mass spectrometry. Food Chem. 2007, 104, 1048-1054. [CrossRef]

43. Nam, J.S.; Jang, H.L.; Rhee, Y.H. Antioxidant Activities and Phenolic Compounds of Several Tissues of Pawpaw (Asimina triloba [L.] Dunal) Grown in Korea. J. Food Chem. 2017, 82, 1827-1833. [CrossRef]

44. Lin, L.-Z.; Harnly, J.M. Identification of hydroxycinnamoylquinic acids of arnica flowers and burdock roots using a standardized lc-dad-esi/ms profiling method. J. Agric. Food Chem. 2008, 56, 10105-10114. [CrossRef]

45. Cádiz-Gurrea, M.; Lozano-Sanchez, J.; Contreras-Gámez, M.; Legeai-Mallet, L.; Fernández-Arroyo, S.; Segura-Carretero, A. Isolation, comprehensive characterization and antioxidant activities of theobroma cacao extract. J. Funct. Foods 2014, 10, 485-498. [CrossRef]

46. Brodowska, K.M. Natural flavonoids: Classification, potential role, and application of flavonoid analogues. Eur. J. Biol. Res. 2017, 7, 108-123.

47. Tourino, S.; Fuguet, E.; Jáuregui, O.; Saura-Calixto, F.; Cascante, M.; Torres, J.L. High-resolution liquid chromatography/electrospray ionization time-of-flight mass spectrometry combined with liquid chromatography/electrospray ionization tandem mass spectrometry to identify polyphenols from grape antioxidant dietary fiber. Rapid Commun. Mass Spectrom. 2008, 22, 3489-3500. [CrossRef] [PubMed]

48. Flamini, R. Recent applications of mass spectrometry in the study of grape and wine polyphenols. Int. Sch. Res. Not. 2013, 2013, 813563. [CrossRef]

49. Baskaran, R.; Pullencheri, D.; Somasundaram, R. Characterization of free, esterified and bound phenolics in custard apple (Annona squamosa L.) fruit pulp by UPLC-ESI-MS/MS. Food Res. Int. 2016, 82, 121-127. [CrossRef]

50. Huang, W.-Y.; Cai, Y.-Z.; Corke, H.; Sun, M. Survey of antioxidant capacity and nutritional quality of selected edible and medicinal fruit plants in hong kong. J. Food Compos. Anal. 2010, 23, 510-517. [CrossRef]

51. Singh, A.; Kumar, S.; Kumar, B. LC-MS identification of proanthocyanidins in bark and fruit of six terminalia species. Nat. Prod. Commun. 2018, 13. [CrossRef]

52. Justino, A.B.; Pereira, M.N.; Vilela, D.D.; Peixoto, L.G.; Martins, M.M.; Teixeira, R.R.; Miranda, N.C.; da Silva, N.M.; de Sousa, R.M.; de Oliveira, A. Peel of araticum fruit (Annona crassiflora mart.) as a source of antioxidant compounds with $\alpha$-amylase, $\alpha$-glucosidase and glycation inhibitory activities. Bioorg. Chem. 2016, 69, 167-182. [CrossRef]

53. Yang, Y.; Zhao, X.J.; Pan, Y.; Zhou, Z. Identification of the chemical compositions of ponkan peel by ultra performance liquid chromatography coupled with quadrupole time-of-flight mass spectrometry. Anal. Methods 2016, 8, 893-903. [CrossRef] 
54. Barreca, D.; Bellocco, E.; Caristi, C.; Leuzzi, U.; Gattuso, G. Flavonoid composition and antioxidant activity of juices from chinotto (citrus $\times$ myrtifolia raf.) fruits at different ripening stages. J. Agric. Food Chem. 2010, 58, 3031-3036. [CrossRef] [PubMed]

55. Zeng, X.; Su, W.; Zheng, Y.; Liu, H.; Li, P.; Zhang, W.; Liang, Y.; Bai, Y.; Peng, W.; Yao, H. Uflc-q-tof-ms/ms-based screening and identification of flavonoids and derived metabolites in human urine after oral administration of exocarpium citri grandis extract. Molecules 2018, 23, 895. [CrossRef]

56. Lin-Wei, C.; Qin, W.; Kun-Ming, Q.; Xiao-Li, W.; Bin, W.; Dan-Ni, C.; Bao-Chang, C.; Ting, C. Chemical profiling of qixue shuangbu tincture by ultra-performance liquid chromatography with electrospray ionization quadrupole-time-of-flight high-definition mass spectrometry (uplc-qtof/ms). Chin. J. Nat. Med. 2016, 14, 141-146.

57. Santos, D.Y.A.C.; Salatino, M.F. Foliar flavonoids of annonaceae from brazil: Taxonomic significance. Phytochemistry 2000, 55, 567-573. [CrossRef]

58. Kadam, D.; Palamthodi, S.; Lele, S. LC-ESI-Q-TOF-MS/MS profiling and antioxidant activity of phenolics from L. Sativum seedcake. J. Food Sci. Technol. 2018, 55, 1154-1163. [CrossRef]

59. Anaya Esparza, L.M.; Montalvo-González, E. Bioactive compounds of soursop (Annona muricata L.) fruit. In Bioactive Compounds in Underutilized Fruits and Nuts; Springer: Berlin/Heidelberg, Germany, 2020; pp. 175-189.

60. Wang, Y.; Vorsa, N.; Harrington, P.d.B.; Chen, P. Nontargeted metabolomic study on variation of phenolics in different cranberry cultivars using uplc-im-hrms. J. Agric. Food Chem. 2018, 66, 12206-12216. [CrossRef]

61. Nebieridze, V.; Skhirtladze, A.; Kemertelidze, E.; Ganzera, M. New flavonoid glycosides from the leaves of tribulus terrestris. Nat. Prod. Commun. 2017, 12. [CrossRef]

62. Liu, Y.; Gan, J.; Liu, W.; Zhang, X.; Xu, J.; Wu, Y.; Yang, Y.; Si, L.; Li, G.; Huang, J. Pharmacokinetics and novel metabolite identification of tartary buckwheat extracts in beagle dogs following co-administration with ethanol. Pharmaceutics 2019, 11, 525. [CrossRef] [PubMed]

63. Guijarro-Díez, M.; Nozal, L.; Marina, M.L.; Crego, A.L. Metabolomic fingerprinting of saffron by lc/ms: Novel authenticity markers. Anal. Bioanal. Chem. 2015, 407, 7197-7213. [CrossRef]

64. Zhao, X.; Zhang, S.; Liu, D.; Yang, M.; Wei, J. Analysis of flavonoids in dalbergia odorifera by ultra-performance liquid chromatography with tandem mass spectrometry. Molecules 2020, 25, 389. [CrossRef]

65. Li, Z.; Zhang, X.; Liao, J.; Fan, X.; Cheng, Y. An ultra-robust fingerprinting method for quality assessment of traditional chinese medicine using multiple reaction monitoring mass spectrometry. J. Pharm. Anal. 2020, 11, 88-95. [CrossRef]

66. Ono, E.; Kim, H.J.; Murata, J.; Morimoto, K.; Okazawa, A.; Kobayashi, A.; Umezawa, T.; Satake, H. Molecular and functional characterization of novel furofuran-class lignan glucosyltransferases from forsythia. Plant Biotechnol. 2010, 27, 317-324. [CrossRef]

67. Wang, X.; Liu, J.; Zhang, A.; Sun, H.; Zhang, Y. Systematic characterization of the absorbed components of acanthopanax senticosus stem. In Serum Pharmacochemistry of Traditional Chinese Medicine; Elsevier: Amsterdam, The Netherlands, 2017; pp. 313-336.

68. Geng, C.-A.; Chen, H.; Chen, X.-L.; Zhang, X.-M.; Lei, L.-G.; Chen, J.-J. Rapid characterization of chemical constituents in saniculiphyllum guangxiense by ultra fast liquid chromatography with diode array detection and electrospray ionization tandem mass spectrometry. Int. J. Mass Spectrom. 2014, 361, 9-22. [CrossRef]

69. Willför, S.; Reunanen, M.; Eklund, P.; Sjöholm, R.; Kronberg, L.; Fardim, P.; Pietarinen, S.; Holmbom, B. Oligolignans in norway spruce and scots pine knots and norway spruce stemwood. Holzforschung 2004, 58, 345-354. [CrossRef]

70. Yang, S.; Shan, L.; Luo, H.; Sheng, X.; Du, J.; Li, Y. Rapid classification and identification of chemical components of schisandra chinensis by uplc-q-tof/ms combined with data post-processing. Molecules 2017, 22, 1778. [CrossRef]

71. Dutra, L.M.; Costa, E.V.; de Souza Moraes, V.R.; de Lima Nogueira, P.C.; Vendramin, M.E.; Barison, A.; do Nascimento Prata, A.P. Chemical constituents from the leaves of annona pickelii (annonaceae). Biochem. Syst. Ecol. 2012, 41, 115-118. [CrossRef]

72. Fan, P.; Hay, A.-E.; Marston, A.; Lou, H.; Hostettmann, K. Chemical variability of the invasive neophytes polygonum cuspidatum sieb. And zucc. And polygonum sachalinensis f. Schmidt ex maxim. Biochem. Syst. Ecol. 2009, 37, 24-34. [CrossRef]

73. Goufo, P.; Singh, R.K.; Cortez, I. A reference list of phenolic compounds (including stilbenes) in grapevine (Vitis vinifera L.) roots, woods, canes, stems, and leaves. Antioxidants 2020, 9, 398. [CrossRef]

74. Roupe, K.A.; Remsberg, C.M.; Yáñez, J.A.; Davies, N.M. Pharmacometrics of stilbenes: Seguing towards the clinic. Curr. Clin. Pharmacol. 2006, 1, 81-101. [CrossRef]

75. Ren, Z.; Nie, B.; Liu, T.; Yuan, F.; Feng, F.; Zhang, Y.; Zhou, W.; Xu, X.; Yao, M.; Zhang, F. Simultaneous determination of coumarin and its derivatives in tobacco products by liquid chromatography-tandem mass spectrometry. Molecules 2016, 21, 1511. [CrossRef]

76. Inkoto, C.L.; Bongo, G.N.; Kapepula, P.; Masengo, C.; Gbolo, B.Z.; Tshiama, C.; Ngombe, N.K.; Iteku, J.B.; Fundu, T.M.; Mpiana P.T. Microscopic features and chromatographic fingerprints of selected congolese medicinal plants: Aframomum alboviolaceum (Ridley) K. Schum, Annona senegalensis Pers. and Mondia whitei (Hook. f.) Skeels. Emergent Life Sci. Res. 2018, 4, 1-10. [CrossRef]

77. Sonkar, N.; Yadav, A.K.; Mishra, P.K.; Jain, P.; Rao, C.V. Evaluation of hepatoprotective activity of annona squamosa leaves and bark extract against carbon tetrachloride liver damage in wistar rats. World J. Pharm. Pharm. Sci. 2016, 5, 1353-1360.

78. Jesionek, W.; Majer-Dziedzic, B.; Horváth, G.; Móricz, Á.M.; Choma, I.M. Screening of antibacterial compounds in Salvia officinalis L. Tincture using thin-layer chromatography—direct bioautography and liquid chromatography_Tandem mass spectrometry techniques. JPC J. Planar Chromatogr. Mod. TLC 2017, 30, 357-362. [CrossRef]

79. Khallouki, F.; Haubner, R.; Ulrich, C.M.; Owen, R.W. Ethnobotanical survey, chemical composition, and antioxidant capacity of methanolic extract of the root bark of annona cuneata oliv. J. Med. Food 2011, 14, 1397-1402. [CrossRef] 
80. Arruda, H.S.; Pereira, G.A.; de Morais, D.R.; Eberlin, M.N.; Pastore, G.M. Determination of free, esterified, glycosylated and insoluble-bound phenolics composition in the edible part of araticum fruit (Annona crassiflora mart.) and its by-products by HPLC-ESI-MS/MS. Food Chem. 2018, 245, 738-749. [CrossRef] [PubMed]

81. Alvionita, M.; Oktavia, I. Bioactivity of Flavonoid in Ethanol Extract of Annona Squamosa L. Fruit as Xanthine Oxidase Inhibitor; IOP Conference Series: Materials Science and Engineering; IOP Publishing: Bristol, UK, 2019; p. 062003. 